\title{
Targeting the Inflammation Culprit in Patients with Psoriasis/Psoriatic Arthritis and Associated Cardiovascular Comorbidities. Is the IL-17 Inhibitor the New Kid on the Block?
}

\author{
Cornel Pater \\ Biopharmaceuticals, Stockholm, Sweden \\ Email: cpater@bahnhof.se
}

How to cite this paper: Pater, C. (2019) Targeting the Inflammation Culprit in Patients with Psoriasis/Psoriatic Arthritis and Associated Cardiovascular Comorbidities. Is the IL-17 Inhibitor the New Kid on the Block? World Journal of Cardiovascular Diseases, 9, 267-294.

https://doi.org/10.4236/wjcd.2019.94024

Received: March 16, 2019

Accepted: April 16, 2019

Published: April 19, 2019

Copyright $\odot 2019$ by author(s) and Scientific Research Publishing Inc. This work is licensed under the Creative Commons Attribution International License (CC BY 4.0).

http://creativecommons.org/licenses/by/4.0/

\section{Open Access}

\begin{abstract}
Despite half-century old, but comprehensive national and international guidance, evidence of clinical effectiveness and widespread agreement on management of risk factors along with sophisticated measures for primary and secondary prevention of major cardiovascular events, cardiovascular disease remains the dominant cause of death and disability world-wide. Life style changes at population-level (e.g., lower salt and saturated fat consumption or reduced/banned amount of industrially-produced trans fatty acids in specific products, etc.) or changes at individual level (e.g., targeting modifiable risk factors/life style changes affecting smoking/tobacco use, poor diet, high blood cholesterol, high blood pressure, insufficient physical activity, overweight/obesity) have reduced coronary heart disease mortality to variable extent in different countries (mostly so reported in Finland, Iceland and Sweden) at the beginning of the new century. Overall, however, cardiovascular mortality is estimated to increase in the next coming years until 2030 at a cost exceeding US $\$ 1044$ billion. Several decades of status quo are also noted in the therapeutic spectrum of cardiovascular disease, mainly consisting of variations to LDL-C lowering agents, antihypertensives, anticoagulants, antiplatelets and fibrinolytics. Most of the therapeutic interventions are "tertiary" in nature (probably some 60\%), meaning that treatment is instituted once the individual has developed a pathologic condition; "secondary prevention" may cover some $25 \%$ - $30 \%$ (meant to prevent re-occurrence of the condition or occurrence of complications) while "primary prevention" is left with $10 \%$ $15 \%$ share (most commonly implying life style changes at individual level and rarely pharmacological intervention). For almost three decades, the so-called inflammatory hypothesis has been promoted as a reasonable pathogenetic theory behind initiation and growth of atherosclerotic plaque (Alexander
\end{abstract}


RW, 1994; Ross R, 1999). With the discovery of molecular and cellular pathways that promote atherosclerosis and the role of cytokines as inflammatory messengers, the concept as such-inflammation, has received a primordial role in atherogenesis. The present review paper aims at ascertaining the role of inflammation as a common pathogenetic denominator of cardiovascular disease in patients primarily treated for their psoriasis and/or psoriatic arthritis.

\section{Keywords}

Psoriasis, Psoriatic Arthritis, Cardiovascular Comorbidities, Inflammation, Cytokines, IL-17

\section{Introduction}

Cardiovascular disease remains a massive public health problem world-wide not only as disease entities clustering under a common umbrella most commonly managed by cardiologists, but also as major comorbidities associated to skin and joint disease in patients with psoriasis and/or psoriatic arthritis. Whether psoriasis initiates the systemic inflammatory march [1] or acts as an amplifier of inflammatory processes in patients with known metabolic disorders, the latter being a scenario that seems to bring about more severe consequences, the ultimate result is a higher prevalence of cardiovascular risk factors including hypertension, diabetes, dyslipidemia, obesity and smoking, and considerably increased risk of developing severe vascular events (including myocardial infarction and stroke) [2]-[41]. Table 1 is a summary of studies carried out since 2010, investigating the risk of serious cardiovascular events in patients with psoriasis (reproduced after Stephen Chu-Sung Hu, Int. J. Mol. Sci. 2017).

Despite the compelling evidence showing increased prevalence of CV risk factors and increased risks of cardiovascular disease (CVD) and mortality among patients with psoriasis/psoriatic arthritis, data suggest that many of these patients are inadequately screened and/or undertreated for CV risk factors [43]-[48]. According to a cross-sectional study in the UK in 2015, patients with psoriasis were more likely to have uncontrolled hypertension as compared with patients without psoriasis [46]. A survey of 127 US dermatologists carried out in 2015 revealed that only approximately 50\% of these, screened patients for hypertension, dyslipidaemia, or diabetes in patients with psoriasis [48]. Notwithstanding the evidence and the guidelines recommending screening and management of $\mathrm{CV}$ risk factors in patients with psoriasis and/or psoriatic arthritis, otherwise applied to the general population [49] [50] [51], justifiably brings dermatologists to the question: refer psoriasis patients with $\mathrm{CV}$ comorbidities to the cardiologist? (As they may do with the psoriasis patients having PsA who are referred to the rheumatologists for diagnostic workup and treatment recommendation). This seems pretty intuitive and easy. Problem remaining is that cardiologists, after running tests and computing a Framingham score to stratify 
Table 1. Studies investigating the risk of severe vascular events (including MI, cerebrovascular disease, and cardiovascular death) in patients with psoriasis.

\begin{tabular}{|c|c|c|c|c|}
\hline Study & $\begin{array}{l}\text { Cardiovascular } \\
\text { Comorbidities }\end{array}$ & $\begin{array}{l}\text { Number of } \\
\text { Patients/Controls }\end{array}$ & Relative Risk & $\begin{array}{l}\text { Population/ } \\
\text { Type of Study }\end{array}$ \\
\hline $\begin{array}{l}\text { Abuabara et al., } \\
2010[30]\end{array}$ & Cardiovascular death & $\begin{array}{l}\text { Severe psoriasis: } 3603 \text {; } \\
\text { Controls: } 14,330\end{array}$ & Hazard ratio: 1.57 (95\% CI 1.26 - 1.96) & $\begin{array}{l}\text { United Kingdom/ } \\
\text { Cohort study }\end{array}$ \\
\hline $\begin{array}{l}\text { Ahlehoff et al., } \\
2011[5]\end{array}$ & $\begin{array}{l}\text { Composite endpoint } \\
\text { (myocardial infarction, } \\
\text { stroke and cardiovascular } \\
\text { death) }\end{array}$ & $\begin{array}{l}\text { Mild psoriasis: } 34,371 \text {; Severe } \\
\text { psoriasis: } 2621 \text {; Controls: } \\
4,003,265\end{array}$ & $\begin{array}{l}\text { Rate ratio: } \\
\text { Composite endpoint: } \\
\text { Mild psoriasis: } 1.20 \text { (95\% CI } 1.14-1.25) \text {; } \\
\text { Severe psoriasis: } 1.58 \text { (95\% CI } 1.36 \text { - 1.82); } \\
\text { Stroke: } \\
\text { Mild psoriasis: } 1.25 \text { (95\% CI } 1.16 \text { - 1.33); } \\
\text { Severe psoriasis: } 1.71 \text { (95\% CI } 1.39 \text { - 2.11); } \\
\text { Myocardial infarction: } \\
\text { Mild psoriasis: } 1.22 \text { (95\% CI } 1.12-1.33) \text {; } \\
\text { Severe psoriasis: } 1.45 \text { (95\% CI } 1.10-1.90) \text {; } \\
\text { Cardiovascular death: } \\
\text { Mild psoriasis: } 1.14 \text { (95\% CI } 1.06-1.22) \text {; } \\
\text { Severe psoriasis } 1.57 \text { (95\% CI } 1.27 \text { - 1.94) }\end{array}$ & $\begin{array}{l}\text { Denmark/Cohort } \\
\text { study }\end{array}$ \\
\hline $\begin{array}{l}\text { Ahlehoff et al., } \\
2011[42]\end{array}$ & $\begin{array}{l}\text { Composite cardiovascular } \\
\text { endpoint (recurrent } \\
\text { myocardial infarction, } \\
\text { stroke and cardiovascular } \\
\text { death) after first time } \\
\text { myocardial infarction }\end{array}$ & $\begin{array}{l}\text { Patients with first time } \\
\text { myocardial infarction; } \\
\text { Psoriasis: } 462 \text {; } \\
\text { Controls: } 48,935\end{array}$ & Hazard ratio: 1.26 (95\% CI 1.06 - 1.54) & $\begin{array}{l}\text { Denmark/Cohort } \\
\text { study }\end{array}$ \\
\hline $\begin{array}{l}\text { Ahlehoff et al., } \\
2012[38]\end{array}$ & Ischemic stroke & $\begin{array}{l}\text { Mild psoriasis: } 36,765 \text {; Severe } \\
\text { psoriasis: } 2793 \text {; Controls: } \\
4,478,926\end{array}$ & $\begin{array}{l}\text { Rate ratio: } \\
\text { Age < } 50 \text { years: } \\
\text { Mild psoriasis: } 1.97 \text { (95\% CI } 1.66-2.34) \text {; } \\
\text { Severe psoriasis: } 2.80 \text { (95\% CI } 1.81-4.34) \text {; } \\
\text { Age } \geq 50 \text { years: } \\
\text { Mild psoriasis: } 1.13 \text { (95\% CI } 1.04-1.21) \text {; } \\
\text { Severe psoriasis: } 1.34 \text { (95\% CI } 1.04-1.71)\end{array}$ & $\begin{array}{l}\text { Denmark/Cohort } \\
\text { study }\end{array}$ \\
\hline $\begin{array}{l}\text { Gelfand et al., } \\
2009[2]\end{array}$ & Stroke & $\begin{array}{l}\text { Mild psoriasis: } 129,143 \\
\text { (controls: } 496,666) \text {; Severe } \\
\text { psoriasis: } 3603 \text { (controls 14,330) }\end{array}$ & $\begin{array}{l}\text { Hazard ratio: } \\
\text { Mild psoriasis: } 1.06 \text { (95\% CI } 1.0 \text { - 1.1); } \\
\text { Severe psoriasis: } 1.43 \text { (95\% CI } 1.1 \text { - 1.9) }\end{array}$ & $\begin{array}{l}\text { United } \\
\text { Kingdom/Cohort } \\
\text { study }\end{array}$ \\
\hline $\begin{array}{l}\text { Kaye et al., } 2008 \\
{[11]}\end{array}$ & $\begin{array}{l}\text { Myocardial infarction } \\
\text { Stroke }\end{array}$ & $\begin{array}{l}\text { Psoriasis: 44,164; Controls: } \\
219,784\end{array}$ & $\begin{array}{l}\text { Hazard ratio: } \\
\text { Myocardial infarction: } \\
1.21 \text { ( } 95 \% \text { CI } 1.10 \text { - } 1.32) \\
\text { Stroke: } 1.12 \text { (95\% CI } 1.00 \text { - } 1.25)\end{array}$ & $\begin{array}{l}\text { United } \\
\text { Kingdom/Cohort } \\
\text { study }\end{array}$ \\
\hline $\begin{array}{l}\text { Lai et al., } 2016 \\
{[25]}\end{array}$ & $\begin{array}{l}\text { Myocardial infarction } \\
\text { Ischemic heart disease } \\
\text { Stroke }\end{array}$ & $\begin{array}{l}\text { Psoriasis: } 520 \text {; Total subjects: } \\
19,065\end{array}$ & $\begin{array}{l}\text { Odds ratio: } \\
\text { Myocardial infarction: } \\
2.24 \text { ( } 95 \% \text { CI } 1.27 \text { - 3.95); Ischemic heart disease: } \\
1.90 \text { ( } 95 \% \text { CI } 1.18 \text { - 3.05); } \\
\text { Stroke: } 1.01 \text { (95\% CI } 0.48-2.16)\end{array}$ & $\begin{array}{l}\text { United States/ } \\
\text { Cross-sectional } \\
\text { study }\end{array}$ \\
\hline $\begin{array}{l}\text { Lan et al., } 2012 \\
{[54]}\end{array}$ & Cerebrovascular disease & $\begin{array}{l}\text { Psoriasis: } 8180 \text {; Controls: } \\
163,600\end{array}$ & Hazard ratio: 1.28 (95\% CI 1.162 - 1.413) & $\begin{array}{l}\text { Taiwan/Retrospective } \\
\text { cohort study }\end{array}$ \\
\hline $\begin{array}{l}\text { Levesque et al., } \\
2013 \text { [27] }\end{array}$ & Myocardial infarction & $\begin{array}{l}\text { Psoriasis: } 31,421 \text {; Controls: } \\
31,421\end{array}$ & Hazard ratio: 1.17 (95\% CI $1.04-1.31)$ & $\begin{array}{l}\text { Canada/Retrospective } \\
\text { cohort study }\end{array}$ \\
\hline $\begin{array}{l}\text { Li et al., } 2012 \\
{[26]}\end{array}$ & $\begin{array}{l}\text { Nonfatal cardiovascular } \\
\text { disease (nonfatal } \\
\text { myocardial infarction, } \\
\text { nonfatal stroke) }\end{array}$ & $\begin{array}{l}\text { Participants: } 96,008 \text { (women); } \\
\text { Psoriasis: } 2463\end{array}$ & $\begin{array}{l}\text { Hazard ratio: } \\
\text { Myocardial infarction: } \\
1.70 \text { ( } 95 \% \text { CI } 1.01-2.86) ; \\
\text { Stroke: } 1.45 \text { (95\% CI } 0.80-2.65)\end{array}$ & $\begin{array}{l}\text { United } \\
\text { States/Cohort study }\end{array}$ \\
\hline
\end{tabular}




\section{Continued}

\begin{tabular}{|c|c|c|c|c|}
\hline $\begin{array}{l}\text { Lin et al., } 2011 \\
{[28]}\end{array}$ & Myocardial infarction & $\begin{array}{l}\text { Psoriasis: 4752; Controls: } \\
23,760\end{array}$ & Hazard ratio: 2.10 (95\% CI $1.27-3.43)$ & $\begin{array}{l}\text { Taiwan/Retrospective } \\
\text { cohort study }\end{array}$ \\
\hline $\begin{array}{l}\text { Mallbris et al., } \\
2004[58]\end{array}$ & Cardiovascular mortality & $\begin{array}{l}\text { Psoriasis inpatients: } 8991 ; \\
\text { Psoriasis outpatients: } 19,757\end{array}$ & $\begin{array}{l}\text { Standardized mortality ratio: } \\
\text { Inpatients: } 1.52 \text { (95\% CI } 1.44-1.60) \text {; } \\
\text { Outpatients: } 0.94 \text { ( } 95 \% \text { CI } 0.89-0.99)\end{array}$ & $\begin{array}{l}\text { Sweden/Cohort } \\
\text { study }\end{array}$ \\
\hline $\begin{array}{l}\text { Mehta et al., } \\
2010[16]\end{array}$ & Cardiovascular mortality & $\begin{array}{l}\text { Severe psoriasis: } 3603 \text {; } \\
\text { Controls: } 14,330\end{array}$ & Hazard ratio: 1.57 (95\% CI 1.26 - 1.96) & $\begin{array}{l}\text { United } \\
\text { Kingdom/Cohort } \\
\text { study }\end{array}$ \\
\hline $\begin{array}{l}\text { Ogdie et al., } \\
2015[23]\end{array}$ & $\begin{array}{l}\text { Major adverse } \\
\text { cardiovascular events } \\
\text { (including myocardial } \\
\text { infarction, cerebrovascular } \\
\text { accidents and } \\
\text { cardiovascular death) }\end{array}$ & $\begin{array}{l}\text { Psoriasis: } 138,424 \text {; Controls: } \\
81,573\end{array}$ & $\begin{array}{l}\text { Hazard ratio: } \\
\text { Mild psoriasis (no DMARD): } \\
1.08 \text { (95\% CI } 1.02 \text { - 1.15); Severe psoriasis } \\
\text { (DMARD user): } \\
1.42 \text { ( } 95 \% \text { CI } 1.17-1.73 \text { ) }\end{array}$ & $\begin{array}{l}\text { United } \\
\text { Kingdom/Cohort } \\
\text { study }\end{array}$ \\
\hline $\begin{array}{l}\text { Prodanovich et } \\
\text { al., } 2009[40]\end{array}$ & $\begin{array}{l}\text { Ischemic heart disease; } \\
\text { Cerebrovascular disease; } \\
\text { Peripheral vascular disease }\end{array}$ & $\begin{array}{l}\text { Psoriasis: 3236; Controls: } \\
2500\end{array}$ & $\begin{array}{l}\text { Odds ratio: } \\
\text { Ischemic heart disease: } \\
1.78 \text { ( } 95 \% \text { CI } 1.51-2.11) \text {; Cerebrovascular } \\
\text { disease: } \\
1.70 \text { (95\% CI } 1.33-2.17) \text {; Peripheral vascular } \\
\text { disease: } \\
1.98 \text { (95\% CI } 1.38-2.82)\end{array}$ & $\begin{array}{l}\text { United } \\
\text { States/Observational } \\
\text { cross-sectional study }\end{array}$ \\
\hline $\begin{array}{l}\text { Shiba et al., } 2016 \\
\text { [29] }\end{array}$ & Coronary heart disease & $\begin{array}{l}\text { Hospital-based population: } \\
\text { 113,065; } \\
\text { Psoriasis: } 1197\end{array}$ & Odds ratio: 1.27 (95\% CI 1.01 - 1.58) & $\begin{array}{l}\text { Japan/Cross-sectional } \\
\text { study }\end{array}$ \\
\hline $\begin{array}{l}\text { Stern et al., } 2011 \\
{[31]}\end{array}$ & Cardiovascular mortality & Severe psoriasis: 1376 & $\begin{array}{l}\text { Standard mortality ratio: } \\
1.02(95 \% \text { CI } 0.90-1.16)\end{array}$ & $\begin{array}{l}\text { United } \\
\text { States/Prospective } \\
\text { cohort study }\end{array}$ \\
\hline $\begin{array}{l}\text { Wakkee et al., } \\
2010[32]\end{array}$ & $\begin{array}{l}\text { Ischemic heart disease } \\
\text { hospitalization }\end{array}$ & $\begin{array}{l}\text { Psoriasis: } 15,820 \text {; Controls: } \\
27,577\end{array}$ & Hazard ratio: 1.05 (95\% CI $0.95-1.17)$ & $\begin{array}{l}\text { Netherlands/Cohort } \\
\text { study }\end{array}$ \\
\hline $\begin{array}{l}\text { Wu et al., } 2015 \\
{[24]}\end{array}$ & Myocardial infarction & $\begin{array}{l}\text { Mild psoriasis: } 10,173 \\
\text { (controls: 50,865); Severe } \\
\text { psoriasis: } 3841 \text { (controls: } \\
19,205 \text { ) }\end{array}$ & $\begin{array}{l}\text { Hazard ratio: } \\
\text { Mild psoriasis: } 1.31 \text { (95\% CI } 1.14 \text { - 1.51); } \\
\text { Severe psoriasis: } 1.28 \text { (95\% CI } 1.02 \text { - 1.60) }\end{array}$ & $\begin{array}{l}\text { United } \\
\text { States/Retrospective } \\
\text { cohort study }\end{array}$ \\
\hline
\end{tabular}

Reproduced after Stephen Chu-Sung Hu, Int. J. Mol. Sci. 2017.

the patients' long term risk, may well recommend the best life style management of risk factors; however, do they have any pharmacologic treatment choice beyond the most obvious one-a lipid lowering agent (?); while staying within the realm of "primary prevention of major adverse cardiovascular events (MACE)"?. This is without doubt a pertinent question, given that there are currently no randomized controlled trials (RCT) providing proof that any established psoriasis treatment can be effective against the risk of CVD. Noteworthy, even the old Framingham Risk Score (FRS) for CV risk underestimates long term risk of MACE in psoriasis patients. Mehta et al.'s study of the impact of psoriasis on the Framingham Risk Score found that the addition of psoriasis warranted a change in CV risk factor treatment plans and goals for over $60 \%$ of 
patients [52] [53].

\section{Anti-inflammatory Treatment Trials}

Markers of inflammation have been shown to be up regulated in different forms of cardiovascular disease and to correlate with vascular risk. As such, systemic inflammation, postulated to be a common pathogenetic pathway for a multitude of diseases, apparently unrelated, is nowadays widely accepted as mechanistic link between psoriasis and cardiometabolic disorders.

This awareness has triggered relentless attempts to prove that classical pharmacological agents, otherwise proven to have desirable efficacy in selected indications, could also have genuine anti-inflammatory effects.

So is the wonderful low dose aspirin, obviously, devoid of anti-inflammatory effect when used for primary prevention of CVD [54].

Rosuvastatin (Crestor), the most prescribed brand name drug in the US, with 22.3 million prescriptions filled and worldwide sales of $\$ 8.2$ bn in 2013 [55] [56], has been shown to reduce CRP levels but no effect whatsoever on the progression and clinical events in aortic stenosis [57]. In addition, rosuvastatin (and the other HMG-CoA reductase inhibitors in the class) are known to increase in $\mathrm{HbA1}$, fasting serum glucose levels and significantly increase the risk for diabetes [58] [59].

The nonsteroidal anti-inflammatory drugs (NSAIDs) and the cyclooxygenase-2 (COX-2) selective inhibitors (the COXIBs) also failed to prove an anti-inflammatory effect and to decrease cardiovascular risk. The COXIBs have even been shown to increase the risk for myocardial infarction [60] [61] [62].

Extensive literature has covered for more than a decade the story around the putative anti-inflammatory effect of methotrexate and of canakinumab.

Alleged, significantly decreased risk of cardiovascular events with low doses of methotrexate (MTX) in both experimental animals as well as in patients has been circulating since 2005 [63]. The association between chronic use of methotrexate and decreased risk of ischemic cardiovascular events (CVE) among patients with psoriatic or rheumatoid arthritis (RA) was investigated using a systematic review and meta-analysis [64]. This meta-analysis was based on seven observational studies with MACE as endpoint and C-reactive protein as surrogate parameter, the "well-known marker of systemic inflammation" [65]. The authors of the study concluded that "methotrexate at low doses, such those used for maintenance therapy of RA, predicted a decreased risk of CVE" [64].

Given the uncertainties inherent in observational trials, Ridker et al (2013) have mounted a randomized, double-blind, placebo-controlled trial of low-dose methotrexate or matching placebo in 4786 patients with previous myocardial infarction or multivessel coronary disease who additionally had either type 2 diabetes or the metabolic syndrome-the CIRT Trial [66]. This trial set out to test the changes in $\mathrm{CRP}$ as well as in interleukin- $1 \beta$ and interleukin- 6 compared to baseline.

After 2.3 years the trial was stopped by the Data Safety Monitoring Board (DSMB). The primary endpoint occurred equally in those treated with MTX (n $=201)$ or placebo $(n=207)$ (hazard ratio, $0.96 ; 95 \%$ confidence interval $[\mathrm{CI}], 0.79$ 
to 1.16). Compared with placebo, MTX treated patients had more liver enzyme elevations, leukopenia, higher MCV values, more anemia and non-basal-cell skin cancers. MTX patients also had more oral ulcers and unintended weight loss. Additionally, MTX did not significantly lower interleukin-1 $\beta$, interleukin-6, or C-reactive protein levels than placebo [67].

The CANTOS trial was supposed to validate the inflammation hypothesis in atherosclerosis, a landmark trial to test whether blocking IL- $1 \beta$, a component of the inflammatory cascade, might translate into improved outcome in the context of secondary prevention of cardiovascular events in patients who have sustained a myocardial infarction [68] [69] [70] [71].

CANTOS was a phase III clinical trial in which canakinumab (Ilaris ${ }^{\circledR}$, Novartis), a monoclonal human IL- $1 \beta$ antibody, on the market in US for more than a decade, approved for the treatment of rare rheumatological conditions, was tested for its presumed anti-inflammatory effects. 10,061 patients (mean age 61 years, $25 \%$ women) with history of myocardial infarction and hsCRP $>2 \mathrm{mg} / \mathrm{L}$ were randomized to receive s.c. injections at 3-month interval (i.e., one of three different doses or placebo).

Patients on the $150 \mathrm{mg}$ dose regimen of canakinumab experienced a $15 \%$ relative risk reduction of a composite of MACE (i.e., nonfatal heart attacks, nonfatal strokes and cardiovascular death). Responses were particularly beneficial for patients whose levels of hsCRP, viewed as a risk factor for heart disease, fell below $2 \mathrm{mg} / \mathrm{L}$ during the trial. Late last year, however, the US Food and Drug Administration issued a complete response letter to Novartis, essentially rejecting the application on the grounds that the submitted data were insufficient to support the company's proposed indication. In Europe, Novartis opted to close the file on the cardiovascular indication when it withdrew from the approval process without addressing questions from regulators. Understandably, the FDA rejection and European withdrawal seem in stark contrast to the enthusiastic reception of CANTOS received in 2017. At the time, financial analysts pegged the anti-inflammatory agent canakinumab as a potential blockbuster, with future sales estimates in the billions, despite the known price tag for $150 \mathrm{mg}$ dose used in CANTOS costing approximately $\$ 73,000$ per year, translating into one quality-adjusted life-year (QALY/year)adding up to \$6.4 million [68] [69] [70] [71].

In the scientific community, on the other side, there is a widespread agreement that CANTOS is an important "proof of principle" for the inflammatory hypothesis in atherosclerosis, at best.

A currently ongoing trial is testing the anti-inflammatory effects of colchicine and spironolactone since February 2017 (Colchicine and Spironolactone in Patients with STEMI/SYNERGY Stent Registry (CLEAR-SYNERGY) (Clinical Trials.gov Identifier: NCT03048825). The CLEAR SYNERGY trial will study the long-term effects of treatments following PCI to treat ST elevation myocardial infarction. These treatments address both the culprit artery (PCI with SYNERGY Stent) as well as the non-culprit arteries (randomization to routine colchicine and spironolactone). 
Another trial to determine the effect of psoriasis treatment (adalimumab, phototherapy, and placebo) oncardiometabolic disease, the vascular inflammation in psoriasis (VIP) trial, tested the hypothesis that psoriasis therapy would improve cardiometabolic biomarkers. Patientshad PASI 12 and BSA10 and were washed out of psoriasis treatments. 97 patients were randomized to adalimumab, nbUVB phototherapy, or placeboin a 1:1:1 ratio and treated for 12 weeks; patients then entered an open-label extension (VIP-E, NCT01866592) so that all received adalimumab for 52 weeks. The primary outcome was FDGPET/CT derived aortic inflammation measured as target-to-background ratio and secondary outcomes were cardiometabolic biomarkers including a novel marker of inflammation, GlycA. There was no difference in change in aortic inflammation at week 12 in the adalimumab group or the nbUVB group or after 52 weeks of adalimumab treatment. Analysis within groups demonstrated a significant reduction in aortic inflammation by $4.09 \%$ (95\% CI-7.78\%, $-0.39 \%)$ in the nbUVB arm only. Neither treatment had impact on metabolic markers (insulin, adiponectin, leptin) whereas only nbUVB increased HDLat 12 weeks. Despite no change in aortic inflammation and minimal impact on lipids and insulin resistance, adalimumab reduced GlycA levels, a biomarker predictive of coronary disease [72].

This study shows the lack of correlation between CRP and IL-6 with aortic inflammation as assessed by FDGPET/CT at 12 and 52 weeks for adalimumab treatment.

Finally, on $26^{\text {th }}$ Feb. 2019 the FDA has issued a safety alert regarding a clinical study that has found a 10-mg, twice-daily dose of tofacitinib (Xeljanz-an oral janus kinase [JAK] inhibitor) increased the risk for pulmonary embolism and mortality in patients with rheumatoid arthritis [73].

Concerns about venous thromboembolic events (VTE) had also been raised during the premarketing trials of another JAK inhibitor, baricitinib (Olumiant), and that drug had been approved only for use in a low dose [73].

Table 2 summarizes studies carried out in patients with psoriasis and CV comorbidities (Reproduced after Stephen Chu-Sung Hu, Int. J. Mol. Sci. 2017).

A few of the examples above, perhaps the ones that mostly attracted both attention and hope as potential breakthrough the rapiesmerit closer appraisal.

Overall, widespread primary and secondary prevention of CVD treatment by lowering of plasma low-density lipoprotein (LDL) is known to prevent subendothelial retention of lipoproteins and thereby decrease inflammatory atherosclerotic disease [84]. However, despite decades of such treatment applied early and bringing LDL to quite low levels, the goal to eliminate atherosclerosis with lipid lowering treatment has not yet been achieved.

The initial hope related to Canakinumab's inflammatory effect was related to findings from mice indicating that neutralization of IL- $1 \beta$ could diminish the atherosclerotic lesion in animals (ignoring the associated finding that deletion of IL- $1 \alpha / \beta$ receptors was worsening plaque stability in a mouse model of advanced atherosclerosis through effects on the extracellular matrix) [85] [86]. Besides, 
Table 2. Studies investigating the effects of different psoriasis treatments on the risk of cardiovascular disease in patients with psoriasis.

\begin{tabular}{|c|c|c|c|c|c|}
\hline Study & $\begin{array}{l}\text { Treatment for } \\
\text { Psoriasis }\end{array}$ & $\begin{array}{l}\text { Cardiovascular } \\
\text { Endpoint }\end{array}$ & Number of Patients & Relative Risk & $\begin{array}{l}\text { Population/ } \\
\text { Type of Study }\end{array}$ \\
\hline $\begin{array}{l}\text { Abuabara et } \\
\text { al., } 2011[74]\end{array}$ & $\begin{array}{l}\text { Systemic } \\
\text { immunomodulatory } \\
\text { therapies (methotrexate, } \\
\text { cyclosporine, alefacept, } \\
\text { efalizumab, adalimumab, } \\
\text { etanercept, infliximab) }\end{array}$ & Myocardial infarction & $\begin{array}{l}\text { Psoriasis: } 25,554 ; \\
\text { Phototherapy: } 4220 ; \\
\text { Systemic treatment: } \\
\text { 20,094; Both } \\
\text { treatments: } 1240\end{array}$ & $\begin{array}{l}\text { Hazard ratio (compared to UVB } \\
\text { phototherapy): } 1.33 \text { ( } 95 \% \text { CI } 0.90-1.96 \text { ) }\end{array}$ & $\begin{array}{l}\text { United States/ } \\
\text { Cohort study }\end{array}$ \\
\hline $\begin{array}{l}\text { Ahlehoff } \\
\text { et al., } 2013 \\
{[75]}\end{array}$ & $\begin{array}{l}\text { Biological agents; } \\
\text { Methotrexate }\end{array}$ & $\begin{array}{l}\text { Cardiovascular death, } \\
\text { myocardial infarction } \\
\text { and stroke }\end{array}$ & $\begin{array}{l}\text { Severe psoriasis: } 2400 \text {; } \\
\text { Biological agents: } 693 \text {; } \\
\text { Methotrexate: } 799 \text {; } \\
\text { Other therapies: } 908\end{array}$ & $\begin{array}{l}\text { Hazard ratio (compared to other } \\
\text { therapies): Biological agents: } \\
0.48 \text { ( } 95 \% \text { CI } 0.17-1.38 \text { ); Methotrexate: } \\
0.50 \text { ( } 95 \% \text { CI } 0.26-0.97)\end{array}$ & $\begin{array}{l}\text { Denmark/ } \\
\text { Retrospective } \\
\text { cohort study }\end{array}$ \\
\hline $\begin{array}{l}\text { Ahlehoff } \\
\text { et al., } 2015 \\
{[76]}\end{array}$ & $\begin{array}{l}\text { Methotrexate; } \\
\text { Cyclosporine; Retinoids; } \\
\text { TNF- } \alpha \text { inhibitors; } \\
\text { Ustekinumab }\end{array}$ & $\begin{array}{l}\text { Cardiovascular } \\
\text { events } \\
\text { (cardiovascular } \\
\text { death, myocardial } \\
\text { infarction, stroke) }\end{array}$ & $\begin{array}{l}\text { Severe psoriasis: } 6902 ; \\
\text { Methotrexate: } 3564 ; \\
\text { Cyclosporine: } 244 ; \\
\text { Retinoids: } \\
\text { 756; TNF- } \alpha \text { inhibitors: } \\
\text { 959; Ustekinumab: } 178\end{array}$ & $\begin{array}{l}\text { Hazard ratio (compared to other } \\
\text { therapies): Methotrexate: } \\
0.53 \text { (95\% CI } 0.34 \text { - 0.83); Cyclosporine: } \\
\text { 1.06 ( } 95 \% \text { CI } 0.26 \text { - 4.27); } \\
\text { Retinoids: } 1.80 \text { ( } 95 \% \text { CI } 1.03 \text { - } 2.96 \text { ); } \\
\text { TNF- } \alpha \text { inhibitors: } 0.46 \text { (95\% CI } 0.22 \text { - 0.98); } \\
\text { Ustekinumab: } 1.52 \text { (95\% CI } 0.47-4.94)\end{array}$ & $\begin{array}{l}\text { Denmark/ } \\
\text { Cohort study }\end{array}$ \\
\hline $\begin{array}{l}\text { Chin et al., } \\
2013 \text { [77] }\end{array}$ & Methotrexate; Retinoid & $\begin{array}{l}\text { Cardiovascular } \\
\text { disease; } \\
\text { Cerebrovascular } \\
\text { disease }\end{array}$ & $\begin{array}{l}\text { Psoriasis patients } \\
\text { without arthritis: } 7648\end{array}$ & $\begin{array}{l}\text { Hazard ratio (compared to no } \\
\text { methotrexate and no retinoid treatment): } \\
\text { Cardiovascular disease: } \\
\text { Methotrexate: } 0.39 \text { (95\% CI } 0.20-0.76 \text { ); } \\
\text { Retinoid } 0.47 \text { ( } 95 \% \text { CI } 0.26-0.83 \text { ); } \\
\text { Cerebrovascular disease: } \\
\text { Methotrexate: } 0.42 \text { (95\% CI } 0.19-0.95) \text {; } \\
\text { Retinoid: } 0.67 \text { (95\% CI } 0.35-1.31 \text { ) }\end{array}$ & $\begin{array}{l}\text { Taiwan/ } \\
\text { Retrospective } \\
\text { cohort study }\end{array}$ \\
\hline $\begin{array}{l}\text { Lan et al., } \\
2012[54]\end{array}$ & Methotrexate; Retinoid & $\begin{array}{l}\text { Cerebrovascular } \\
\text { disease }\end{array}$ & $\begin{array}{l}\text { Psoriasis: } 8180 \text {; } \\
\text { Methotrexate: } 258 \text {; } \\
\text { Retinoid: } 193\end{array}$ & $\begin{array}{l}\text { Hazard ratio (compared to no } \\
\text { methotrexate and no retinoid treatment): } \\
\text { Methotrexate: } 0.50 \text { (95\% CI } 0.27-0.92) \text {; } \\
\text { Retinoid: } 0.70 \text { ( } 95 \% \text { CI } 0.39-1.23)\end{array}$ & $\begin{array}{l}\text { Taiwan/ } \\
\text { Retrospective } \\
\text { cohort study }\end{array}$ \\
\hline $\begin{array}{l}\text { Prodanovich } \\
\text { et al., } 2005 \\
{[78]}\end{array}$ & Methotrexate & $\begin{array}{l}\text { Vascular disease } \\
\text { (including } \\
\text { cardiovascular disease, } \\
\text { cerebrovascular disease, } \\
\text { atherosclerosis) }\end{array}$ & Psoriasis: 7615 & $\begin{array}{l}\text { Relative risk (compared to no } \\
\text { methotrexate treatment): Methotrexate: } \\
0.73 \text { ( } 95 \% \text { CI } 0.55-0.98) \text {; Low } \\
\text { cumulative dose methotrexate: } \\
0.50 \text { ( } 95 \% \text { CI } 0.31-0.79)\end{array}$ & $\begin{array}{l}\text { United States/ } \\
\text { Retrospective } \\
\text { cohort study }\end{array}$ \\
\hline $\begin{array}{l}\text { Wu et al., } \\
2012[79]\end{array}$ & TNF inhibitor & Myocardial infarction & $\begin{array}{l}\text { Psoriasis: } 8845 \text {; TNF } \\
\text { inhibitor: } 1673\end{array}$ & $\begin{array}{l}\text { Hazard ratio (compared to topical } \\
\text { therapy): TNF inhibitor: } \\
0.50(95 \% \text { CI } 0.32-0.79)\end{array}$ & $\begin{array}{l}\text { United States/ } \\
\text { Retrospective } \\
\text { cohort study }\end{array}$ \\
\hline $\begin{array}{l}\text { Wu et al., } \\
2013[80]\end{array}$ & $\begin{array}{l}\text { TNF inhibitor; } \\
\text { Oral/phototherapy }\end{array}$ & Myocardial infarction & $\begin{array}{l}\text { Psoriasis: 8845; } \\
\text { Caucasians: } \\
4645 \text { (TNF inhibitor: } \\
\text { 857; Oral/phototherapy: } \\
\text { 1011; Topical: 2777); } \\
\text { Non-Caucasians: } 4200 \\
\text { (TNF inhibitor: } 816 \text {; } \\
\text { Oral/phototherapy: } \\
\text { 1086; Topical: } 2298 \text { ) }\end{array}$ & $\begin{array}{l}\text { Hazard ratio (compared to topical } \\
\text { therapy): Caucasians: TNF inhibitors: } \\
0.35 \text { ( } 95 \% \text { CI } 0.20 \text { - } 0.62 \text { ); } \\
\text { Oral/phototherapy: } \\
0.36 \text { (95\% CI } 0.22 \text { - } 0.59 \text { ); } \\
\text { Non-Caucasians: TNF inhibitors: } 0.27 \\
\text { (95\% CI } 0.11 \text { - } 0.67) \text {; Oral/phototherapy: } \\
0.58 \text { (95\% CI } 0.32-1.04 \text { ) }\end{array}$ & $\begin{array}{l}\text { United States/ } \\
\text { Retrospective } \\
\text { cohort study }\end{array}$ \\
\hline
\end{tabular}




\begin{tabular}{|c|c|c|c|c|c|}
\hline $\begin{array}{l}\text { Wu et al., } \\
2013[81]\end{array}$ & $\begin{array}{l}\text { TNF inhibitor } \\
\text { (etanercept or } \\
\text { monoclonal antibody) }\end{array}$ & Myocardial infarction & $\begin{array}{l}\text { Etanercept: } 976 \text {; } \\
\text { Monoclonal antibody: } \\
\text { 217; Topical therapy: } \\
5075\end{array}$ & $\begin{array}{l}\text { Hazard ratio (compared to topical } \\
\text { agents): Etanercept: } \\
0.53 \text { ( } 95 \% \text { CI } 0.31-0.92) \text {; Monoclonal } \\
\text { antibody: } 0.25 \text { ( } 95 \% \text { CI } 0.06-1.03 \text { ) }\end{array}$ & $\begin{array}{l}\text { United States/ } \\
\text { Retrospective } \\
\text { cohort study }\end{array}$ \\
\hline $\begin{array}{l}\text { Wu et al., } \\
2014[82]\end{array}$ & TNF inhibitor & Myocardial infarction & $\begin{array}{l}\text { Psoriasis (treated with } \\
\text { TNF inhibitor): } 846 \text {; } \\
\text { Psoriasis } \\
\text { (not treated with TNF } \\
\text { inhibitor): } 7172\end{array}$ & $\begin{array}{l}\text { Hazard ratio (compared to psoriasis } \\
\text { patients not treated with TNF } \\
\text { inhibitors): } \\
0.26(95 \% \text { CI } 0.12-0.56)\end{array}$ & $\begin{array}{l}\text { United States/ } \\
\text { Retrospective } \\
\text { cohort study }\end{array}$ \\
\hline $\begin{array}{l}\text { Wu et al., } \\
2017 \text { [83] }\end{array}$ & TNF inhibitor & $\begin{array}{l}\text { Major cardiovascular } \\
\text { events (myocardial } \\
\text { infarction, stroke or } \\
\text { transient ischemic } \\
\text { attack, unstable } \\
\text { angina) }\end{array}$ & $\begin{array}{l}\text { TNF inhibitor: } 9148 \text {; } \\
\text { Methotrexate: } 8581\end{array}$ & $\begin{array}{l}\text { Hazard ratio (compared to } \\
\text { methotrexate): Major cardiovascular } \\
\text { event: } \\
0.55 \text { ( } 95 \% \text { CI } 0.45 \text { - } 0.67 \text { ) Myocardial } \\
\text { infarction: } 0.49 \text { ( } 95 \% \text { CI } 0.34-0.71 \text { ); } \\
\text { Stroke or TIA: } 0.55 \text { ( } 95 \% \text { CI } 0.42-0.71 \text { ); } \\
\text { Unstable angina: } 0.58 \text { (95\% CI } 0.41 \text { - } \\
0.82 \text { ) }\end{array}$ & $\begin{array}{l}\text { United States/ } \\
\text { Retrospective } \\
\text { cohort study }\end{array}$ \\
\hline
\end{tabular}

Reproduced after Stephen Chu-Sung Hu, Int. J. Mol. Sci. 2017.

the potential benefit of long-term use of canakinumab in humans at high risk for atherosclerotic vascular disease might need to be substantial enough to counter its high price and the increased risk of infection, which was $67 \%$ in a 2 -yearcryopyrinassociated periodic syndromes (CAPS)trial vs. $25 \%$ for placebo [87].

Finally, low-dose MTX is known to be a relatively safe and well-tolerated drug; it has, however, several mild and usually self-limited side effects, including nausea, stomatitis, and fatigue, but long-term use has rarely been associated with more important adverse effects, such as hepatotoxicity, pulmonary disease, and infection [86]. However, if low-dose MTX were effective in atherosclerosis but would require long-term use, these side effects might become more important. Moreover, the risk of liver injury and infection is increased in subjects with type 2 diabetes [86] [88], which represents a sizable percentage of the high-risk CAD population that would be considered for this drug.

\section{Novel Therapeutic Directions}

The atherosclerotic plaque is considered the culprit of a series of sequential events taking place upfront (angina pectoris, unstable angina/acute pulmonary oedema), culminating with an acute myocardial infarction and followed by different degrees of heart failure, cardiorenal syndrome, etc. [89].

Inflammation of the vessel wall is involved in all stages of the course of atherothrombotic disease, from the development of early lesions to the occurrence of clinical events. Significant advances in recent years have largely improved our understanding of this phenomenon and of its influence not only on atherogenesis, but also on other intimately related disorders such as arterial hypertension or the metabolic syndrome. Emerging imaging technologies (e.g., the FDGPET/CT [90]) as well as measurement of serum concentrations of novel biomarkers (TNF $\alpha$, ILs, e.g., GlycA (nuclear magnetic resonance signal) [91] 
and high mobility group box (HMGB1 [92])) offer the possibility to monitor and quantify the degree of chronic vascular inflammation in vivo, as well as to test new therapeutic options, especially in the field of inflammation signaling.

The risk for major cardiovascular events as well as vascular inflammation increases with psoriasis severity and its duration independent of traditional CV risk factors [6] [22] [93]-[104].

Inflammation as a hallmark of both $\mathrm{PsO} / \mathrm{PsA}$ and atherosclerosis implies common pathogenic features, including local and systemic immunologic processes, inflammatory cytokine/chemokine profiles, and inflammatory markers (Figure 1) [34] [38] [105].

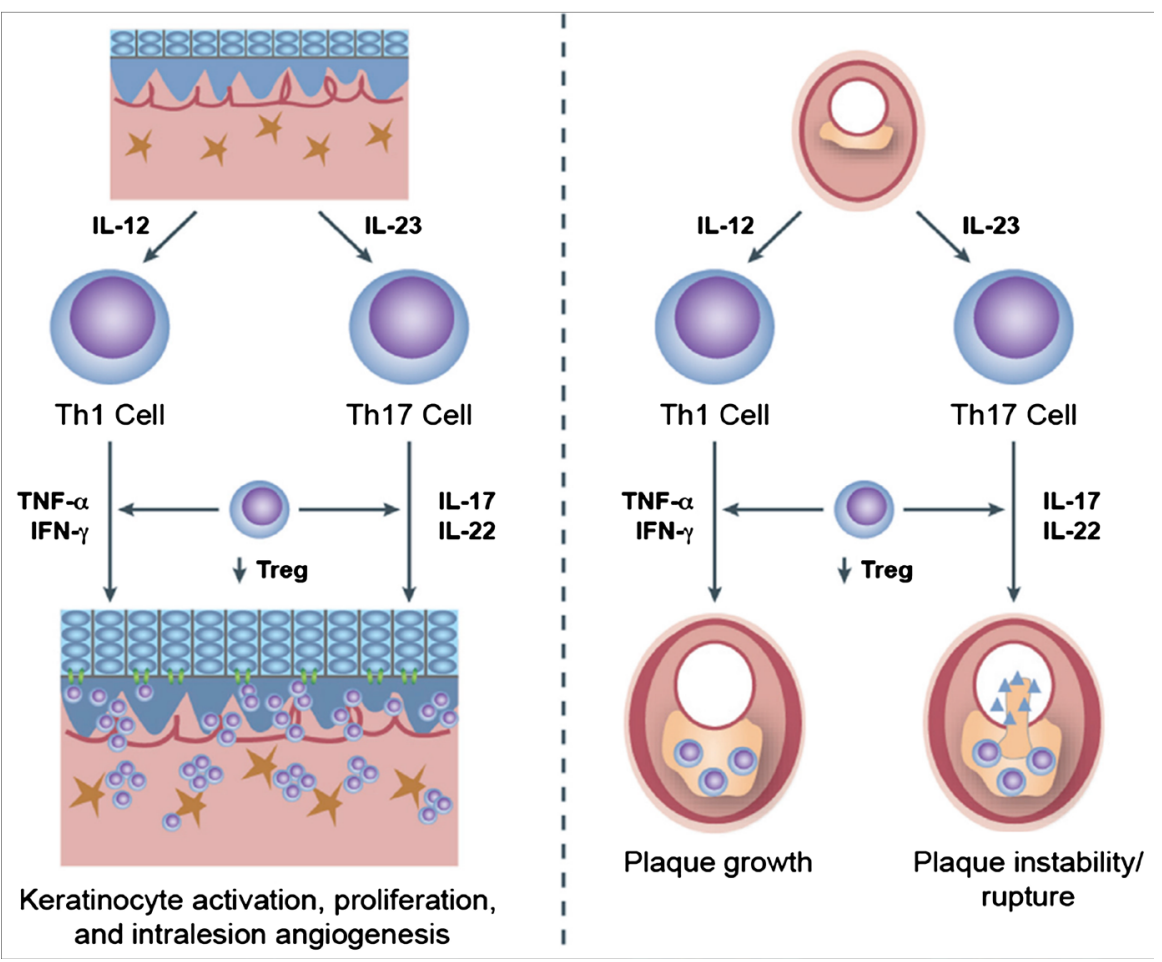

Adapted with permission from Armstrong AW, Voyles SV, Armstrong EJ, Fuller EN, Rutledge JC. Exp Dermatol 2011

Figure 1. Psoriasis and atherosclerosis have similar underlying immunologic mechanisms. Inpsoriasis (left), myeloid dendritic cells secrete interleukin (IL) 12 and IL-23, which results in T-cell differentiation into type 1 helper $\mathrm{T}$ (Th1) and type 17 helper $\mathrm{T}$ (Th17) cell subtypes. Th1cells in psoriatic lesions secrete tumor necrosis factor-a (TNF-a) and interferon gamma (IFN-g), leading to keratinocyte activation and expression of adhesion molecules, including intercellular adhesion molecule 1 and keratinocyte proliferation. Th17 cells secrete IL-17 and IL-22, which promote both keratinocyte proliferation and intralesional angiogenesis. Decreased levels of regulatory T cells (Tregs) lead to altered levels of transforming growth factor-b, which promotes further Th1 and Th17 cell activation. In atherosclerosis (right), endothelial activation at sites of nascent arterial plaque promotes monocyte and lymphocyte extravasation and subsequent macrophage and dendritic cell elaboration of IL-12 and IL-23. Differentiated Th1cells promote further atherosclerotic plaque growth, whereas Th17 cells promote intraplaque neoangiogensis and intraplaque hemorrhage. Increased levels of intraplaque IL-17 may lead to further weakening of the fibrous cap, with subsequent plaque rupture and myocardial infarction. 
Lymphocytes expressing CD4+ receptor on the surface, also known as Thelper cells (Th) have fundamental role in the adaptive immune response. They are commonly classified into Th1, Th2, Th17, and T-reg subsets based on the effector cytokines released, with a prevalence of IL-12 and IFN- $\gamma$ in Th1, IL-4, and IL-13 in Th2, IL-17, and IL-23 in Th17, and finally IL-10 and TGF- $\beta$ in T-regs [106]. These cytokines are then involved in mounting a particular type of inflammatory response [27] [39] [107] [108] as indicated in Figure 2. The Th17 lineage produces IL-17A, IL-17F, IL-22 and IL-21.

The pro-inflammatory cytokine IL-23, composed by the two subunits $\mathrm{p} 19$ and p40, is mainly produced by inflammatory Dendritic Cells (DCs) within the inflamed skin [35], with the additional contribution of macrophages and keratinocytes [109] [110]. IL-23 induces the expansion and the maintenance of the Th 17 subsets of $\mathrm{T}$ cells.

The Th17 lymphocytes are characterised by the expression of the transcription factor Retinoic acid receptor-Related Orphan receptor-t (ROR- $\gamma$ t) and the signalling pathway Janus Kinase (JAK)-Signal Transducer and Activator of Transcription (STAT). They differentiate from naïve $\mathrm{T}$ cells in the presence of three potential combinations of cytokines: 1) IL- 6 and Transforming Growth Factor- $\beta$ (TGF $\beta$ ), with the additional potentiating effect of IL- $1 \beta$ and TNF $\alpha$; 2) IL-21 and TGF $\beta$; and 3) IL-6, IL-1 $\beta$ and IL-23 [11]. The IL-17 family includes six members, namely IL-17A, B, C, D, E and F. Of these, IL-17A is the principal effector

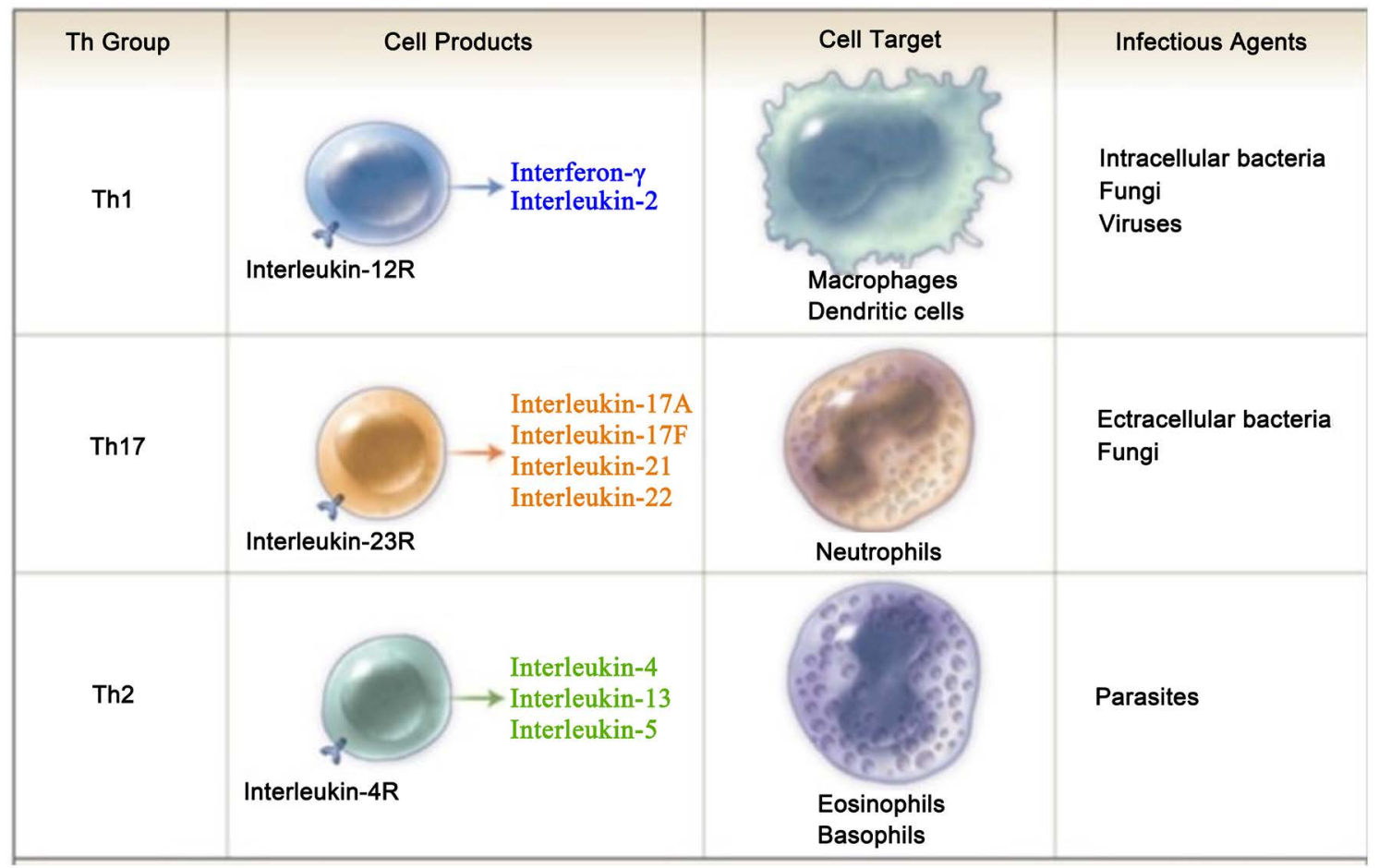

Miossec, P. et al. NEJM 2009.

Figure 2. Helper T-cell (Th) subgroups and effector functions. The cytokine profile (including key cytokine receptors as denoted by R), the effector cell type that is activated, and the corresponding types of infections are shown for each Th subgroup. 
of the IL-17-related inflammatory activity in PsO/PsA and atherosclerosis. IL-17 can exert its effects by binding members of the IL-17-Receptors (IL-17R) family (i.e., IL-17RA, RB, RC, RD and RE).

Functionally, the Th17 cells can be categorised into host protective cells or pathogenic inflammatory cells. What role they exercise depends on the type of cytokines promoting their differentiation. Commonly, IL-23-activated Th17 cells trigger autoimmunity and chronic inflammation; conversely, TGF $\beta$ and IL-6 promote pathogenic Th17 cells important in tissue defence and integrity [111]. As such, concomitant increase in IL-17 and IL-10 levels and reduction in IFN- $\gamma$ is likely to limit lesion development and to promote plaque stability, whereas simultaneous production of IL-17 and IFN- $\gamma$ is seems to promote lesion progression and plaque instability [112].

Upon activation, Th17 cells release effector molecules able to trigger a variety of target cells such as osteoclasts, B-cells and macrophages, which are responsible for the disease-specific inflammatory response (Figure 3) [113].

Overall, IL-17 stimulation can increase keratinocytes proliferation, neo-angiogenesis, recruitment and activation of mast cells, neutrophils and macrophages, while reducing the expression of adhesion molecules thus favouring the disruption of the skin barrier and arterial plaque instability.

\section{Experimental Studies Exploring IL-17A}

In a recent publication, Schüler et al. [114] describe ground-breaking findings from having analysed three murine models with varying severity of psoriasis-like skin disease and their associated vascular function and inflammation:

- K14-IL-17Aind/+ mice with keratinocyte-specific IL-17A over expression and an early onset severe psoriasis-like phenotype,

- homozygous CD11c-IL-17 Aind/ind and heterozygous CD11c-IL-17 Aind/+mice over expressing IL-17A in CD11c+ cells leading to a delayed onset of moderate psoriasis-like skin disease, and

- the acute model of imiquimod-induced psoriasis-like skin inflammation (IMQ).

Their data demonstrate a direct link between systemic IL-17A levels and the severity of skin disease and vascular inflammation/dysfunction and confirm previous theory extended by Wohn et al. [115] indicating that a certain threshold of systemic IL-17A must be exceeded for vascular dysfunction to develop. These findings are aligned with those coming from two other research groups [116] [117] suggesting a link between the severity of skin disease and the amount of cutaneous and systemic IL-17A with the level of peripheral oxidative stress and vascular dysfunction. Further on, the IMQ model [114] with moderate to severe psoriatic skin lesion displayed only early signs of vascular inflammation and peripheral oxidative stress, very much in line with the natural course of psoriatic skin disease leading to only moderately up-regulated IL-17A levels in the skin and peripheral blood [114].

Saleh et al. [117] showed that arterial thrombus formation was attenuated in a mouse model of psoriasis under IL-17A inhibition (Li et al., 2018), indicating 


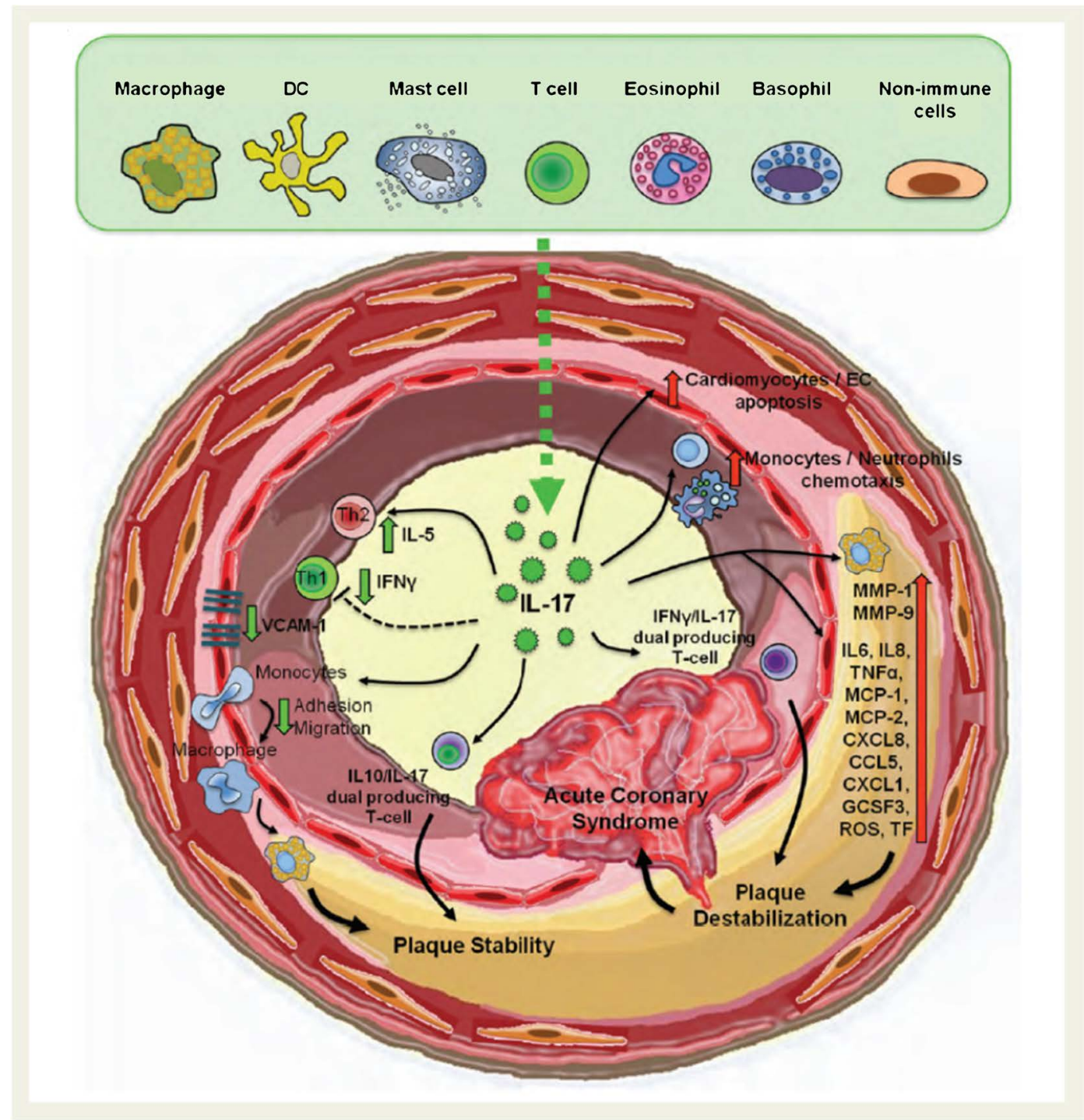

Adapted with permission from Liuzzo, G. et al. EHJ 2013.

Figure 3. Proatherogenic and atheroprotective effects of IL-17. Several cell types produce IL-17. IL-17 exerts proatherogenic effects by inducing the production of cytokines, chemokines, and matrix metalloproteinases. IL-17 also promotes G-CSF-mediated granulopoiesis and the recruitment of immune cells. Moreover, IL-17 induces apoptosis of endothelial cells and cardiomyocytes by activating caspase-3 and caspase-9, and up-regulating the Bax/Bcl-2 ratio. The atheroprotective effect of IL-17 seems to be mediated at least in part by the regulation of other cytokines (reduction of IFN-g and enhancement of IL-5) and by its inhibitory effect on VCAM-1 expression, an adhesion molecule mediating the accumulation of monocytes and $\mathrm{T}$ cells within the lesions. Abbreviations: CCL5, chemokine (C-C motif) ligand 5; CXCL1, chemokine (C-X-C motif) ligand 1; CXCL8, chemokine (C-X-C motif) ligand 8; EC, endothelial cells; GCSF, granulocyte-colony stimulating factor; IFN, interferon; IL, interleukin; $\mathrm{MCP}$, monocyte chemotactic protein; MMP, matrix metalloproteinases; ROS, reactive oxygen species; TF, tissue factor; TNF, tumour necrosis factor; VCAM-1, vascular cell adhesion molecule-1.

that targeting cytokines that mediate psoriatic inflammation may indeed improve cardiovascular comorbidities.

Perhaps the most compelling piece of experimental research in this area comes from the group of Li-Hao Huang et al. [118] from Washington University 
School of Medicine in St. Louis. The researchers managed to narrow down the common inflammatory pathway of the psoriasis-affected skin lesions and vascular stiffness in atherosclerosis caused by the thickening of the collagenous matrix. The thickening is known to be caused by an excess of collagen in the skin and blood vessel, respectively. By use of a light-sensitive form of high-density lipoprotein (HDL) that fluoresces when hit with a laser, the researchers could see that HDL cholesterol was delayed in getting out of the bloodstream in the mice that received the compound, a phenomenon present in both the skin and the internal arteries near the heart. In addition, the skin and blood vessels were more densely interlaced with collagen and more resistant to stretching. Further, when the researchers fed mice a high-cholesterol diet for three weeks, the mice in the experimental psoriasis group developed significantly larger cholesterol deposits in their blood vessels.

The findings suggest that psoriasis-affected skin lesions program interleukin-17-producing $\mathrm{T}$ cells in draining lymph nodes to distal skin and later to arteries. There, these cells mediate thickening of the collagenous matrix, such that larger molecules including lipoproteins become entrapped. HDL transit can be rescued by depleting CD4+ T cells or by neutralizing interleukin-17. Thus, interleukin-17 can reduce lipoprotein trafficking and increase vascular stiffness by, at least in part, remodeling collagen, the researchers concluded [118].

In parallel with, as well as following the animal experimental studies, many observational studies in patients with a variety of different inflammatory diseases have brought about evidence about IL-17 being a potent inflammatory factor with a key role in the pathogenetic mechanisms of these disease entities.

In particular, convincing evidence indicates that IL-17 is key player in multiple stages of the atherosclerotic coronary artery disease by promoting arterial wall inflammation, platelet aggregation, accelerated thrombosis and plaque vulnerability. All these changes translate into increased risk of all-cause and cardiovascular death in patients in whom there is a clustering of classical risk factors and particular inflammatory diseases such as PsO, PsA, RA, etc. [119] [120] [121] [122] [123].

Most recently, a study by Mehta et al. [124] brings additional data in support of the role IL-17 has in patients with psoriasis and associated cardiovascular risk factors. Patients in the study, known with moderate to severe psoriasis were biologic-naïve at baseline and with low cardiovascular risk based on Framingham scores.

Most of these patients were treated with biologics, while those who declined biologics were treated with topicals and/or light therapy (the latter group served as the reference group for the study). A total of 89 patients received treatment with a TNF-alpha inhibitor (etanercept or adalimumab), interleukin (IL)-12/23 inhibitor (ustekinumab), or interleukin-17 inhibitor (ixekizumab or secukinumab), while the non-biologic group included 32 patients.

At one-year follow-up, the biologic-treated patient had significant improvements in coronary artery plaque as measured by coronary computed tomogra- 
phy angiography with no appreciable impact on lipids, glucose, or body mass index. This was associated with a reduction at one-year in total coronary plaque burden by $5 \%(P=0.009)$ and driven mainly by a reduction in non-calcified plaque burden $(P=0.005)$, fibrofatty burden, and the size of the necrotic core. There was a significant decrease in non-calcified plaque burden favouring biologic over non-biologic treatment.

By contrast, there was a significant increase in fibrofatty plaque burden, amounting to a $38 \%$ increase $(P=0.004)$, and a non-significant $33 \%$ increase in necrotic burden, according to the report in those not treated with biologic therapy for their severe psoriasis.

Patients treated with biologics had a significant reduction in high sensitivity C-reactive protein (hsCRP), while patients treated with topicals and/or light therapy did not.

Unexpectedly (or perhaps not), exposure to the three different class of biologics revealed that after a year of treatment with anti-IL-17 there was a significantly greater reduction in coronary plaque burden versus both IL-12/23 treatment and no biologic treatment. For anti-TNF therapy, the reduction in non-calcified coronary plaque burden was only significant versus non-biologic treated patients, though Mehta et al. [124] emphasized the observational nature of their study and thereby the limitations of the study findings.

Another recent article by Zhang et al. [125] explored behaviour of cytokines belonging to the Th1, Th2 and Th17 lymphocytes in patients with acute myocardial infarction (AMI-19 cases), unstable angina (UA-25 cases), stable angina (SA-21 cases) and 20 healthy controls. Serum levels of IL-17 and IFN $\gamma$ in the AMI and UA groups were statistically significantly higher than those in the control and SA group.

\section{Novel Biomarkers for Ascertaining Systemic Inflammation}

GlycA by FDG-PET/CT is a novel, relatively recently validated assay that quantifies the nuclear magnetic resonance signal from $\mathrm{N}$-acetylglucosamine and $\mathrm{N}$-acetylgalactosamine moieties of plasma glycoproteins. It has been proposed as an alternative to C-reactive protein (CRP) as a newer biomarker of systemic inflammation [91]. FDG-PET/CT enables measurement of in vivo whole-body inflammation, including high sensitivity for macrophage activity in the early, subclinical inflammation of atherosclerosis [90]. FDG is taken up by cells in proportion to their metabolic activity and quantifies vascular inflammation as a standardized uptake value. The measurement of vascular inflammation by FDG-PET/CT has evolved as an acceptable surrogate inflammatory marker that can be modulated with therapy and may prognosticate stroke and myocardial infarction [126].

Change from baseline in vessel wall target-to-background ratio is the variable looked at for assessing aorta inflammation [127].

In a pilot study of six patients with moderate to severe psoriasis versus controls, FDG-PET/CT demonstrated increased metabolic activity in the liver, in- 
creased clinical and subclinical joint inflammation, and increased aortic inflammation even after adjustment for cardiovascular risk factors. Inflammation observed in the aorta suggested that aortas of patients with psoriasis were aged ten years compared to their age-matched control cohorts [127].

Coronary CT angiography (CCTA) is used to investigate coronary atherosclerosis, enabling identification of rupture-prone plaques, and has been proposed as an independent predictor of cardiovascular events [128].

Coronary artery calcification, as detected by CT, has been found to be more prevalent in patients with psoriasis compared to controls [129] [130] [131] [132]. Coronary artery calcium increases in patients with psoriasis in a similar manner to that of patients with type 2 diabetes after adjustment for body mass index [3]. Excessive quantity of epicardial adipose tissue, a risk factor for coronary artery disease, has also been found to be increased in CT studies of psoriasis patients in comparison to controls [129] [133].

\section{Discussion}

A huge amount of critical information that has been accrued during more than a decade might well enable translation of basic research into properly designed and powered, global randomized clinical trials, to substantiate the therapeutic potential of monoclonal antibodies and/or innovative small molecules targeting cytokines belonging to the IL-17 class. Available evidence suggests that the therapeutic potential covers not only psoriasis/psoriatic arthritis but also atherosclerosis, hypertension, liver and kidney disease, multiple sclerosis and many other inflammatory disease entities [134]-[139]. Such a scenario would certainly need to imply that overall increased circulatory IL-17 levels would trigger inflammation in specific tissues/organs in the absence of psoriatic skin lesions. This concept is however not proven yet, leaving open the axiom that blocking IL-17 signaling pathways might prove to have preventive or therapeutic effects in patients with $\mathrm{PsO} / \mathrm{PsA}$ and associated cardiovascular comorbidities (CV risk factors and/or established clinical entities).

There are several IL-17 blocking agents available on the market:

US EU Japan

\begin{tabular}{ccccc}
\hline $\begin{array}{c}\text { secukinumab [Cosentyx, Zafrez] } \\
\text { brodalumab [Siliq, Lumicef, and Kyntheum] }\end{array}$ & Novartis & 2015 & 2015 & 2014 \\
Axekizumab [Taltz] & Eli Lilly & 2016 & 2016 & 2016 \\
\hline
\end{tabular}

Secukinumab and Ixekizumab are both IL-17A neutralizing while brodalumab blocks the IL-17RA receptor subunit. Over the coming years, UCB is expected to launch its IL-17A/IL-17F agent-bimekizumab. These are all monoclonal antibodies however, more recently there has also been focus on the small molecule oral therapeutics (Bristol-Myers Squibb's BMS-986195 [140], Can-Fite Biopharma's piclidenoson [141] and ABY-035, a very small protein drug that is un- 
dergoing ph 2 study in PsO-Affibody AB, Stockholm [142]).

Other than the monoclonal antibodies, highly specific and potent inhibitors targeting Th17 specific transcription factor ROR $\gamma$ t have been identified and found to be highly effective [143].

Finally, a highly innovative IL-17 blocking agent may come from Nuevolution $\mathrm{AB}$ (Copenhagen). Nuevolution's small molecules may offer access to both topical (e.g. cream based) treatment as well as safe tablet-based treatment [144].

Recent results from the VIP-S80 study evaluating cardiovascular outcomes in patients with psoriasis treated with secukinumab are far from meeting expectations [145]. Further on, potential anti-inflammatory effect of secukinumab is tested currently in the ObePso-S92 study [146] by evaluating changes in adipose tissue in patients with psoriasis treated with secukinumab. Likewise, real-world data derived from the Corrona Psoriasis Registry might provide valuable data on the topic [147].

One may wonder, how come that secukinumab, highly efficacious in treating the psoriasis and psoriatic arthritis symptoms, fails to show a meaningful effect on inflammation. There is obviously no straightforward answer to this question other than assuming that the great heterogeneity encountered in the natural course of disease intricacies (i.e., $\mathrm{PsO} / \mathrm{PsA} / \mathrm{CV}$ comorbidities), compounded by the complexity of physiopathological and immunological mechanisms playing in require out-of-the box thinking, thorough selection of the population segments to be explored as well as ingenious study designs and carefully selected endpoints.

Taken together, currently available clinical and experimental data do lend strong translational knowledge to key study design elements and enable highly focused clinical development strategy for any IL-17 inhibitor agent targeting $\mathrm{PsO} / \mathrm{PsA}$ and the clinical cardiovascular burden simultaneously. In particular, such a strategy would have to focus on appropriate selection of patient population to be targeted, timing of $1^{\text {st }}$ efficacy analysis, endpoints and, nonetheless, careful dose finding/dose regimen considerations (along with suitable monitoring of safety/tolerability/immunogenicity aspects of such an undertaking).

\section{Conflicts of Interest}

The author declares no conflicts of interest regarding the publication of this paper.

\section{References}

[1] Boehncke, W.H., Boehncke, S., Tobin, A.M. and Kirby, B. (2011) The "Psoriatic March": A Concept of How Severe Psoriasis May Drive Cardiovascular Comorbidity. Experimental Dermatology, 20, 303-307. https://doi.org/10.1111/j.1600-0625.2011.01261.x

[2] Gelfand, J.M., Dommasch, E.D., Shin, D.B., Azfar, R.S., Kurd, S.K., Wang, X. and Troxel, A.B. (2009) The Risk of Stroke in Patients with Psoriasis. Journal of Investigative Dermatology, 129, 2411-2418. https://doi.org/10.1038/jid.2009.112 
[3] Mansouri, B., Kivelevitch, D., Natarajan, B., Joshi, A.A., Ryan, C., Benjegerdes, K., Schussler, J.M., Rader, D.J., Reilly, M.P., Menter, A. and Mehta, N.N. (2016) Comparison of Coronary Artery Calcium Scores between Patients with Psoriasis and Type 2 Diabetes. JAMA Dermatology, 152, 1244-1253. https://doi.org/10.1001/jamadermatol.2016.2907

[4] Augustin, M. and Radtke, M.A. (2014) Quality of Life in Psoriasis Patients. Expert Review of Pharmacoeconomics and Outcomes Research, 14, 559-568. https://doi.org/10.1586/14737167.2014.914437

[5] Quintard, B., Constant, A., Bouyssou-Gauthier, M.L., Paul, C., Truchetet, F., Thomas, P., Guiguen, Y. and Taieb, A. (2011) Validation of a Specific Health-Related Quality of Life Instrument in a Large Cohort of Patients with Psoriasis: The QualiPso Questionnaire. Acta Dermato-Venereologica, 91, 660-665. https://doi.org/10.2340/00015555-1137

[6] Gelfand, J.M., Neimann, A.L., Shin, D.B., Wang, X., Margolis, D.J. and Troxel, A.B. (2006) Risk of Myocardial Infarction in Patients with Psoriasis. JAMA, 296, 1735-1741. https://doi.org/10.1001/jama.296.14.1735

[7] Furue, M., Tsuji, G., Chiba, T. and Kadono, T. (2017) Cardiovascular and Metabolic Diseases Comorbid with Psoriasis: Beyond the Skin. Internal Medicine, 56, 1613-1619.

[8] Shahwan, K.T. and Kimball, A.B. (2015) Psoriasis and Cardiovascular Disease. Medical Clinics of North America, 99, 1227-1242. https://doi.org/10.1016/j.mcna.2015.08.001

[9] Takeshita, J., Grewal, S., Langan, S.M., Mehta, N.N., Ogdie, A., Van Voorhees, A.S. and Gelfand, J.M. (2017) Psoriasis and Comorbid Diseases: Epidemiology. Journal of the American Academy of Dermatology, 76, 377-390. https://doi.org/10.1016/j.jaad.2016.07.064

[10] Ryan, C. and Kirby, B. (2015) Psoriasis Is a Systemic Disease with Multiple Cardiovascular and Metabolic Comorbidities. Dermatologic Clinics, 33, 41-55. https://doi.org/10.1016/j.det.2014.09.004

[11] Kaye, J.A., Li, L. and Jick, S.S. (2008) Incidence of Risk Factors for Myocardial Infarction and Other Vascular Diseases in Patients with Psoriasis. British Journal of Dermatology, 159, 895-902. https://doi.org/10.1111/j.1365-2133.2008.08707.x

[12] Shah, K., Mellars, L., Changolkar, A. and Feldman, S.R. (2017) Real-World Burden of Comorbidities in US Patients with Psoriasis. Journal of the American Academy of Dermatology, 77, 287-292. https://doi.org/10.1016/j.jaad.2017.03.037

[13] Ma, L., Li, M., Wang, H., Li, Y. and Bai, B. (2014) High Prevalence of Cardiovascular Risk Factors in Patients with Moderate or Severe Psoriasis in Northern China. Archives of Dermatological Research, 306, 247-251. https://doi.org/10.1007/s00403-013-1437-3

[14] Masson, W., Rossi, E., Galimberti, M.L., Krauss, J., Estrada, J.N., Galimberti, R. and Cagide, A. (2017) Mortality in Patients with Psoriasis. A Retrospective Cohort Study. Medicina Clínica, 148, 483-488. https://doi.org/10.1016/j.medcli.2016.12.011

[15] Gelfand, J.M., Troxel, A.B., Lewis, J.D., Kurd, S.K., Shin, D.B., Wang, X., Margolis, D.J. and Strom, B.L. (2007) The Risk of Mortality in Patients with Psoriasis: Results from a Population-Based Study. Archives of Dermatology, 143, 1493-1499. https://doi.org/10.1001/archderm.143.12.1493

[16] Mehta, N.N., Azfar, R.S., Shin, D.B., Neimann, A.L., Troxel, A.B. and Gelfand, J.M. (2010) Patients with Severe Psoriasis Are at Increased Risk of Cardiovascular Mortality: Cohort Study Using the General Practice Research Database. European Heart 
Journal, 31, 1000-1006. https://doi.org/10.1093/eurheartj/ehp567

[17] Siegel, D., Devaraj, S., Mitra, A., Raychaudhuri, S.P., Raychaudhuri, S.K. and Jialal, I. (2013) Inflammation, Atherosclerosis, and Psoriasis. Clinical Reviews in Allergy and Immunology, 44, 194-204. https://doi.org/10.1007/s12016-012-8308-0

[18] Augustin, M., Vietri, J., Tian, H. and Gilloteau, I. (2017) Incremental Burden of Cardiovascular Comorbidity and Psoriatic Arthritis among Adults with Moderate-to-Severe Psoriasis in Five European Countries. Journal of the European Academy of Dermatology and Venereology, 31, 1316-1323. https://doi.org/10.1111/jdv.14286

[19] Feldman, S.R., Tian, H., Gilloteau, I., Mollon, P. and Shu, M. (2017) Economic Burden of Comorbidities in Psoriasis Patients in the United States: Results from a Retrospective U.S. Database. BMC Health Services Research, 17, 337. https://doi.org/10.1186/s12913-017-2278-0

[20] Benson, M.M. and Frishman, W.H. (2015) The Heartbreak of Psoriasis: A Review of Cardiovascular Risk in Patients with Psoriasis. Cardiology in Review, 23, 312-316.

[21] Coumbe, A.G., Pritzker, M.R. and Duprez, D.A. (2014) Cardiovascular Risk and Psoriasis: Beyond the Traditional Risk Factors. The American Journal of Medicine, 127, 12-18. https://doi.org/10.1016/j.amjmed.2013.08.013

[22] Armstrong, E.J., Harskamp, C.T. and Armstrong, A.W. (2013) Psoriasis and Major Adverse Cardiovascular Events: A Systematic Review and Meta-Analysis of Observational Studies. Journal of the American Heart Association, 2, e000062. https://doi.org/10.1161/JAHA.113.000062

[23] Ogdie, A., Yu, Y., Haynes, K., Love, T.J., Maliha, S., Jiang, Y., Troxel, A.B., Hennessy, S., Kimmel, S.E., Margolis, D.J., et al. (2015) Risk of Major Cardiovascular Events in Patients with Psoriatic Arthritis, Psoriasis and Rheumatoid Arthritis: A Population-Based Cohort Study. Annals of the Rheumatic Diseases, 74, 326-332. https://doi.org/10.1136/annrheumdis-2014-205675

[24] Wu, J.J., Choi, Y.M. and Bebchuk, J.D. (2015) Risk of Myocardial Infarction in Psoriasis Patients: A Retrospective Cohort Study. Journal of Dermatological Treatment, 26, 230-234. https://doi.org/10.3109/09546634.2014.952609

[25] Lai, Y.C. and Yew, Y.W. (2016) Psoriasis as an Independent Risk Factor for Cardiovascular Disease: An Epidemiologic Analysis Using a National Database. Journal of Cutaneous Medicine and Surgery, 20, 327-333.

[26] Li, W.Q., Han, J.L., Manson, J.E., Rimm, E.B., Rexrode, K.M., Curhan, G.C. and Qureshi, A.A. (2012) Psoriasis and Risk of Nonfatal Cardiovascular Disease in U.S. Women: A Cohort Study. British Journal of Dermatology, 166, 811-818. https://doi.org/10.1111/j.1365-2133.2011.10774.x

[27] Levesque, A., Lachaine, J. and Bissonnette, R. (2013) Risk of Myocardial Infarction in Canadian Patients with Psoriasis: A Retrospective Cohort Study. Journal of $\mathrm{Cu}$ taneous Medicine and Surgery, 17, 398-403. https://doi.org/10.2310/7750.2013.13052

[28] Lin, H.W., Wang, K.H., Lin, H.C. and Lin, H.C. (2011) Increased Risk of Acute Myocardial Infarction in Patients with Psoriasis: A 5-Year Population-Based Study in Taiwan. Journal of the American Academy of Dermatology, 64, 495-501. https://doi.org/10.1016/j.jaad.2010.01.050

[29] Shiba, M., Kato, T., Funasako, M., Nakane, E., Miyamoto, S., Izumi, T., Haruna, T. and Inoko, M. (2016) Association between Psoriasis Vulgaris and Coronary Heart Disease in a Hospital-Based Population in Japan. PLoS ONE, 11, e 0149316. https://doi.org/10.1371/journal.pone.0149316 
[30] Abuabara, K., Azfar, R.S., Shin, D.B., Neimann, A.L., Troxel, A.B. and Gelfand, J.M. (2010) Cause-Specific Mortality in Patients with Severe Psoriasis: A Population-Based Cohort Study in the U.K. British Journal of Dermatology, 163, 586-592. https://doi.org/10.1111/j.1365-2133.2010.09941.x

[31] Stern, R.S. and Huibregtse, A. (2011) Very Severe Psoriasis Is Associated with Increased Noncardiovascular Mortality but Not with Increased Cardiovascular Risk. Journal of Investigative Dermatology, 131, 1159-1166. https://doi.org/10.1038/jid.2010.399

[32] Wakkee, M., Herings, R.M. and Nijsten, T. (2010) Psoriasis May Not Be an Independent Risk Factor for Acute Ischemic Heart Disease Hospitalizations: Results of a Large Population-Based Dutch Cohort. Journal of Investigative Dermatology, 130, 962-967. https://doi.org/10.1038/jid.2009.321

[33] Dowlatshahi, E.A., Kavousi, M., Nijsten, T., Ikram, M.A., Hofman, A., Franco, O.H. and Wakkee, M. (2013) Psoriasis Is Not Associated with Atherosclerosis and Incident Cardiovascular Events: The Rotterdam Study. Journal of Investigative Dermatology, 133, 2347-2354. https://doi.org/10.1038/jid.2013.131

[34] Ahlehoff, O., Gislason, G., Lamberts, M., Folke, F., Lindhardsen, J., Larsen, C.T., Torp-Pedersen, C. and Hansen, P.R. (2015) Risk of Thromboembolism and Fatal Stroke in Patients with Psoriasis and Nonvalvular Atrial Fibrillation: A Danish Nationwide Cohort Study. Journal of Internal Medicine, 277, 447-455.

https://doi.org/10.1111/joim.12272

[35] Samarasekera, E.J., Neilson, J.M., Warren, R.B., Parnham, J. and Smith, C.H. (2013) Incidence of Cardiovascular Disease in Individuals with Psoriasis: A Systematic Review and Meta-Analysis. Journal of Investigative Dermatology, 133, 2340-2346. https://doi.org/10.1038/jid.2013.149

[36] Xu, T. and Zhang, Y.H. (2012) Association of Psoriasis with Stroke and Myocardial Infarction: Meta-Analysis of Cohort Studies. British Journal of Dermatology, 167, 1345-1350. https://doi.org/10.1111/bjd.12002

[37] Chiang, C.H., Huang, C.C., Chan,W.L., Huang, P.H., Chen, Y.C., Chen, T.J., Chung, C.M., Lin, S.J., Chen, J.W. and Leu, H.B. (2012) Psoriasis and Increased Risk of Ischemic Stroke in Taiwan: A Nationwide Study. The Journal of Dermatology, 39, 279-281. https://doi.org/10.1111/j.1346-8138.2011.01401.x

[38] Ahlehoff, O., Gislason, G.H., Jorgensen, C.H., Lindhardsen, J., Charlot, M., Olesen, J.B., Abildstrom, S.Z., Skov, L., Torp-Pedersen, C. and Hansen, P.R. (2012) Psoriasis and Risk of Atrial Fibrillation and Ischaemic Stroke: A Danish Nationwide Cohort Study. European Heart Journal, 33, 2054-2064.

https://doi.org/10.1093/eurheartj/ehr285

[39] Ahlehoff, O., Gislason, G.H., Charlot, M., Jorgensen, C.H., Lindhardsen, J., Olesen, J.B., Abildstrom, S.Z., Skov, L., Torp-Pedersen, C. and Hansen, P.R. (2011) Psoriasis Is Associated with Clinically Significant Cardiovascular Risk: A Danish Nationwide Cohort Study. Journal of Internal Medicine, 270, 147-157. https://doi.org/10.1111/j.1365-2796.2010.02310.x

[40] Prodanovich, S., Kirsner, R.S., Kravetz, J.D., Ma, F., Martinez, L. and Federman, D.G. (2009) Association of Psoriasis with Coronary Artery, Cerebrovascular, and Peripheral Vascular Diseases and Mortality. Archives of Dermatology, 145, 700-703. https://doi.org/10.1001/archdermatol.2009.94

[41] Raaby, L., Ahlehoff, O. and De Thurah, A. (2017) Psoriasis and Cardiovascular Events: Updating the Evidence. Archives of Dermatological Research, 309, 225-228. https://doi.org/10.1007/s00403-016-1712-1 
[42] Ahlehoff, O., Gislason, G.H., Lindhardsen, J., Olesen, J.B., Charlot, M., Skov, L., Torp-Pedersen, C. and Hansen, P.R. (2011) Prognosis Following First-Time Myocardial Infarction in Patients with Psoriasis: A Danish Nationwide Cohort Study. Journal of Internal Medicine, 270, 237-244. https://doi.org/10.1111/j.1365-2796.2011.02368.x

[43] Mallbris, L., Akre, O., Granath, F., Yin, L., Lindelof, B., Ekbom, A. and Stahle-Backdahl, M. (2004) Increased Risk for Cardiovascular Mortality in Psoriasis Inpatients but Not in Outpatients. European Journal of Epidemiology, 19, 225-230. https://doi.org/10.1023/B:EJEP.0000020447.59150.f9

[44] Parsi, K.K., Brezinski, E.A., Lin, T.C., et al. (2012) Are Patients with Psoriasis Being Screened for Cardiovascular Risk Factors? A Study of Screening Practices and Awareness among Primary Care Physicians and Cardiologists. Journal of the American Academy of Dermatology, 67, 357-362.

https://doi.org/10.1016/j.jaad.2011.09.006

[45] Kimball, A.B., Szapary, P., Mrowietz, U., et al. (2012) Underdiagnosis and Undertreatment of Cardiovascular Risk Factors in Patients with Moderate to Severe Psoriasis. Journal of the American Academy of Dermatology, 67, 76-85. https://doi.org/10.1016/j.jaad.2011.06.035

[46] Takeshita, J., Wang, S., Shin, D.B., et al. (2015) Effect of Psoriasis Severity on Hypertension Control: A Population-Based Study in the United Kingdom. JAMA Dermatology, 151, 161-169. https://doi.org/10.1001/jamadermatol.2014.2094

[47] Alamdari, H.S., Gustafson, C.J., Davis, S.A., et al. (2013) Psoriasis and Cardiovascular Screening Rates in the United States. Journal of Drugs in Dermatology, 12, e14-e19.

[48] Manalo, I.F., Gilbert, K.E. and Wu, J.J. (2015) Survey of Trends and Gaps in Dermatologists' Cardiovascular Screening Practices in Psoriasis Patients: Areas Still in Need of Improvement. Journal of the American Academy of Dermatology, 73, 872-874.

[49] Friedewald, V.E., Cather, J.C., Gelfand, J.M., et al. (2008) AJC Editor's Consensus: Psoriasis and Coronary Artery Disease. American Journal of Cardiology, 102, 1631-1643. https://doi.org/10.1016/j.amjcard.2008.10.004

[50] Eckel, R.H., Jakicic, J.M., Ard, J.D., et al. (2014) 2013 AHA/ACC Guideline on Lifestyle Management to Reduce Cardiovascular Risk: A Report of the American College of Cardiology/American Heart Association Task Force on Practice Guidelines. Circulation, 129, S76-S99. https://doi.org/10.1161/01.cir.0000437740.48606.d1

[51] Mehta, N.N., Krishnamoorthy, P., Yu, Y.D., Khan, O., Raper, A., Van Voorhees, A., Troxel, A.B. and Gelfand, J.M. (2012) The Impact of Psoriasis on Ten-Year Framingham Risk. Journal of the American Academy of Dermatology, 67, 796-798. https://doi.org/10.1016/j.jaad.2012.05.016

[52] Mehta, N.N., Yu, Y., Pinnelas, R., Krishnamoorthy, P., Shin, D.B., Troxel, A.B., et al. (2011) Attributable Risk Estimates of Severe Psoriasis on Major Adverse Cardiac events. The American Journal of Medicine, 124, e771-e776.

[53] Peters, M.J., Symmons, D.P., McCarey, D., Dijkmans, B.A., Nicola, P., Kvien, T.K., et al. (2010) EULAR Evidence-Based Recommendations for Cardiovascular Risk Management in Patients with Rheumatoid Arthritis and Other Forms of Inflammatory Arthritis. Annals of the Rheumatic Diseases, 69, 325-331. https://doi.org/10.1136/ard.2009.113696

[54] Hennekens, C.H., Dyken, M.L. and Fuster, V. (1997) Aspirin as a Therapeutic Agent in Cardiovascular Disease: A Statement for Healthcare Professionals from the 
American Heart Association. Circulation, 96, 2751-2753. https://doi.org/10.1161/01.CIR.96.8.2751

[55] IMS Health (2014) IMS Health. 1 October 2013 to 30 September 2014.

[56] IMS Health (2013) Top Global Products 2013.

[57] Chan K.L., Dumesnil, J.G. and Tam, J. (2011) Effect of Rosuvastatin on C-Reactive Protein and Progression of Aortic Stenosis. American Heart Journal, 161, 1133-1139.

[58] Koh, K.K., Quon, M.J., Sakuma, I., et al. (2013) Differential Metabolic Effects of Rosuvastatin and Pravastatin in Hypercholesterolemic Patients. International Journal of Cardiology, 166, 509-515. https://doi.org/10.1016/j.ijcard.2011.11.028

[59] Brault, M., Ray, J., Gomez, Y., Mantzoros, C.S. and Daskalopoulou, S.S. (2014) Statin Treatment and New-Onset Diabetes: A Review of Proposed Mechanisms. Metabolism, 63, 735-745. https://doi.org/10.1016/j.metabol.2014.02.014

[60] Pijak, M.R., Huzicka, I. and Gazdik, F. (2005) Coxibs and Cardiovascular Risk. Canadian Medical Association Journal, 173, 852. https://doi.org/10.1503/cmaj.1050128

[61] Kearney, P.M., Baigent, C., Godwin, J., Halls, H., Emberson, J.R. and Patrono, C. (2006) Do Selective Cyclo-Oxygenase-2 Inhibitors and Traditional Non-Steroidal Anti-Inflammatory Drugs Increase the Risk of Atherothrombosis? Meta-Analysis of Randomized Trials. British Medical Journal, 332, 1302-1308. https://doi.org/10.1136/bmj.332.7553.1302

[62] Nashel, D.J. (1986) Is Atherosclerosis a Complication of Long-Term Corticosteroid Treatment? The American Journal of Medicine, 80, 925-929. https://doi.org/10.1016/0002-9343(86)90639-X

[63] Lan, C.C., Ko, Y.C., Yu, H.S., Wu, C.S., Li, W.C., Lu, Y.W., Chen, Y.C., Chin, Y.Y., Yang, Y.H. and Chen, G.S. (2012) Methotrexate Reduces the Occurrence of Cerebrovascular Events among Taiwanese Psoriatic Patients: A Nationwide Population-Based Study. Acta Dermato-Venereologica, 92, 349-352. https://doi.org/10.2340/00015555-1283

[64] De Vecchis, R., Baldi, C. and Palmisani, L. (2016) Protective Effects of Methotrexate against Ischemic Cardiovascular Disorders in Patients Treated for Rheumatoid Arthritis or Psoriasis: Novel Therapeutic Insights Coming from a Meta-Analysis of the Literature Data. Anatolian Journal of Cardiology, 16, 2-9.

[65] Haverkate, F., Thompson, S.G., Pyke, S.D., Gallimore, J.R. and Pepys, M.B. (1997) Production of C-Reactive Protein and Risk of Coronary Events in Stable and Unstable Angina. The Lancet, 349, 462-466. https://doi.org/10.1016/S0140-6736(96)07591-5

[66] Everett, B. et al. (2013) Rationale and Design of the Cardiovascular Inflammation Reduction Trial: A Test of the Inflammatory Hypothesis of Atherothrombosis. American Heart Journal, 166, 199-207. https://doi.org/10.1016/j.ahj.2013.03.018

[67] Ridker, P.M., et al. (2018) Low-Dose Methotrexate for the Prevention of Atherosclerotic Events. The New England Journal of Medicine, 380, 752-762.

[68] Ridker, P.M., Danielson, E., Fonseca, F.A.H., et al. (2008) Rosuvastatin to Prevent Vascular Events in Men and Women with Elevated C-Reactive Protein. The New England Journal of Medicine, 359, 2195-2207. https://doi.org/10.1056/NEJMoa0807646

[69] Ridker, P.M., Everett, B.M., Thuren, T., et al. (2017) Antiinflammatory Therapy with Canakinumab for Atherosclerotic Disease. The New England Journal of Medicine, 377, 1119-1131. https://doi.org/10.1056/NEJMoa1707914

[70] Ridker, P.M., MacFadyen, J.G., Thuren, T., Everett, B.M., Libby, P., Glynn, R.J. and 
CANTOS Trial Group (2017) Effect of Interleukin-1 $\beta$ Inhibition with Canakinumab on Incident Lung Cancer in Patients with Atherosclerosis: Exploratory Results from a Randomised, Double-Blind, Placebo-Controlled Trial. The Lancet, 390, 1833-1842.

[71] Sehested, T.S.G., Bjerre, J., Ku, S., et al. (2019) Cost-Effectiveness of Canakinumab for Prevention of Recurrent Cardiovascular Events. JAMA Cardiology, 4, 218-135. https://doi.org/10.1001/jamacardio.2018.4566

[72] Gelfand, G.M. et al. (2018) 393 A Trial to Determine the Effect of Psoriasis Treatment (Adalimumab, Phototherapy, and Placebo) on Cardiometabolic Disease: The Vascular Inflammation in Psoriasis (VIP) Trial. Journal of Investigative Dermatology, 138, S67. https://doi.org/10.1016/j.jid.2018.03.400

[73] https://www.medpagetoday.com/rheumatology/arthritis/78224

[74] Abuabara, K., Lee, H. and Kimball, A.B. (2011) The Effect of Systemic Psoriasis Therapies on the Incidence of Myocardial Infarction: A Cohort Study. British Journal of Dermatology, 165, 1066-1073. https://doi.org/10.1111/j.1365-2133.2011.10525.x

[75] Ahlehoff, O., Skov, L., Gislason, G., Lindhardsen, J., Kristensen, S.L., Iversen, L., Lasthein, S., Gniadecki, R., Dam, T.N., Torp-Pedersen, C., et al. (2013) Cardiovascular Disease Event Rates in Patients with Severe Psoriasis Treated with Systemic Anti-Inflammatory Drugs: A Danish Real-World Cohort Study. Journal of Internal Medicine, 273, 197-204. https://doi.org/10.1111/j.1365-2796.2012.02593.x

[76] Ahlehoff, O., Skov, L., Gislason, G., Gniadecki, R., Iversen, L., Bryld, L.E., Lasthein, S., Lindhardsen, J., Kristensen, S.L., Torp-Pedersen, C., et al. (2015) Cardiovascular Outcomes and Systemic Anti-Inflammatory Drugs in Patients with Severe Psoriasis: 5-Year Follow-Up of a Danish Nationwide Cohort. Journal of the European Academy of Dermatology and Venereology, 29, 1128-1134. https://doi.org/10.1111/jdv.12768

[77] Chin, Y.Y., Yu, H.S., Li, W.C., Ko, Y.C., Chen, G.S., Wu, C.S., Lu, Y.W., Yang, Y.H. and Lan, C.C. (2013) Arthritis as an Important Determinant for Psoriatic Patients to Develop Severe Vascular Events in Taiwan: A Nation-Wide Study. Journal of the European Academy of Dermatology and Venereology, 27, 1262-1268.

[78] Prodanovich, S., Ma, F., Taylor, J.R., Pezon, C., Fasihi, T. and Kirsner, R.S. (2005) Methotrexate Reduces Incidence of Vascular Diseases in Veterans with Psoriasis or Rheumatoid Arthritis. Journal of the American Academy of Dermatology, 52, 262-267. https://doi.org/10.1016/j.jaad.2004.06.017

[79] Wu, J.J., Poon, K.Y., Channual, J.C. and Shen, A.Y. (2012) Association between Tumor Necrosis Factor Inhibitor Therapy and Myocardial Infarction Risk in Patients with Psoriasis. Archives of Dermatology, 148, 1244-1250. https://doi.org/10.1001/archdermatol.2012.2502

[80] Wu, J.J. and Poon, K.Y. (2013) Association of Ethnicity, Tumor Necrosis Factor Inhibitor Therapy, and Myocardial Infarction Risk in Patients with Psoriasis. Journal of the American Academy of Dermatology, 69, 167-168.

https://doi.org/10.1016/j.jaad.2013.02.019

[81] Wu, J.J., Poon, K.Y. and Bebchuk, J.D. (2013) Association between the Type and Length of Tumor Necrosis Factor Inhibitor Therapy and Myocardial Infarction Risk in Patients with Psoriasis. Journal of Drugs in Dermatology, 12, 899-903.

[82] Wu, J.J., Poon, K.Y. and Bebchuk, J.D. (2014) Tumor Necrosis Factor Inhibitor Therapy and Myocardial Infarction Risk in Patients with Psoriasis, Psoriatic Arthritis, or Both. Journal of Drugs in Dermatology, 13, 932-934.

[83] Wu, J.J., Guerin, A., Sundaram, M., Dea, K., Cloutier, M. and Mulani, P. (2017) 
Cardiovascular Event Risk Assessment in Psoriasis Patients Treated with Tumor Necrosis Factor-Alpha Inhibitors versus Methotrexate. Journal of the American Academy of Dermatology, 76, 81-90. https://doi.org/10.1016/j.jaad.2016.07.042

[84] Tabas, I., Williams, K.J. and Borén, J. (2007) Subendothelial Lipoprotein Retention as the Initiating Process in Atherosclerosis: Update and Therapeutic Implications. Circulation, 116, 1832-1844. https://doi.org/10.1161/CIRCULATIONAHA.106.676890

[85] Alexander, M.R., et al. (2012) Genetic Inactivation of IL-1 Signaling Enhances Atherosclerotic Plaque Instability and Reduces Outward Vessel Remodeling in Advanced Atherosclerosis in Mice. Journal of Clinical Investigation, 122, 70. https://doi.org/10.1172/JCI43713

[86] Tabas, I. and Glass, C.K. (2013) Anti-Inflammatory Therapy in Chronic Disease: Challenges and Opportunities. Science, 339, 166-172.

https://doi.org/10.1126/science.1230720

[87] Moreira-Navarrete,V., et al. (2013) Effectiveness of Canakinumab In a Cryopyrin-Associated Periodic Syndrome Cohort. 2013 ACR/ARHP Annual Meeting, A Single Center Experience, Abstract Number: 1205, 25-30 October 2013, San Diego, CA.

[88] Stamp, L., et al. (2006) The Use of Low Dose Methotrexate in Rheumatoid Arthritis-Are We Entering a New Era of Therapeutic Drug Monitoring and Pharmacogenomics? Biomedicine and Pharmacotherapy, 60, 678-687. https://doi.org/10.1016/j.biopha.2006.09.007

[89] Pater, C. and Severin T. (2013) Management of Acute Heart Failure. Is There a Paradigm Shift around the Corner? World Journal of Cardiovascular Diseases, 3, 1-7.

[90] Tahara, N., Kai, H., Ishibashi, M., Nakaura, H., Kaida, H., Baba, K., Hayabuchi, N. and Imaizumi, T. (2006) Simvastatin Attenuates Plaque Inflammation: Evaluation by Fluorodeoxyglucose Positron Emission Tomography. Journal of the American College of Cardiology, 48, 1825-1831. https://doi.org/10.1016/j.jacc.2006.03.069

[91] Joshi, A.A., Lerman, J.B., Aberra, T.M., Afshar, M., Teague, H.L., Rodante, J.A., Krishnamoorthy, P., Ng, Q., Aridi, T.Z., Salahuddin, T., et al. (2016) GlycA Is a Novel Biomarker of Inflammation and Subclinical Cardiovascular Disease in Psoriasis. Circulation Research, 119, 1242-1253. https://doi.org/10.1161/CIRCRESAHA.116.309637

[92] Liao, Y., Jiang, H. and Hu, X. (2016) Increased Serum IL-17A Is Associated with HMGB1 in Coronary Artery Disease. International Journal of Clinical and Experimental Medicine, 9, 11772-11779.

[93] Harrington, L.E., Hatton, R.D., Mangan, P.R., et al. (2005) Interleukin 17-Producing $\mathrm{CD}^{+}{ }^{+}$Effector $\mathrm{T}$ Cells Develop via a Lineage Distinct from the $\mathrm{T}$ Helper Type 1 and 2 Lineages. Nature Immunology, 6, 1123-1132. https://doi.org/10.1038/ni1254

[94] Bettelli, E., Korn, T. and Kuchroo, V.K. (2007) Th17: The Third Member of the Effector T Cell Trilogy. Current Opinion in Immunology, 19, 652-657. https://doi.org/10.1016/j.coi.2007.07.020

[95] Kim, T.G., Kim, S. and Lee, M.G. (2017) The Origin of Skin Dendritic Cell Network and Its Role in Psoriasis. International Journal of Molecular Sciences, 19, 42. https://doi.org/10.3390/ijms19010042

[96] Piskin, G., Sylva-Steenland, R.M.R., Bos, J.D. and Teunissen, M.B.M. (2006) In Vitro and in Situ Expression of IL-23 by Keratinocytes in Healthy Skin and Psoriasis Lesions: Enhanced Expression in Psoriatic Skin. The Journal of Immunology, 176, 
1908-1915. https://doi.org/10.4049/jimmunol.176.3.1908

[97] McKenzie, B.S., Kastelein, R.A. and Cua, D.J. (2006) Understanding the IL-23-IL-17 Immune Pathway. Trends in Immunology, 27, 17-23. https://doi.org/10.1016/j.it.2005.10.003

[98] Veldhoen, M. (2014) Interleukin 17 Is a Chief Orchestrator of Immunity. Nature Immunology, 18, 612-621. https://doi.org/10.1038/ni.3742

[99] Gaffen, S.L., Jain, R., Garg, A.V. and Cua, D.J. (2014) The IL-23-IL-17 Immune Axis: From Mechanisms to Therapeutic Testing. Nature Reviews Immunology, 14, 585-600. https://doi.org/10.1038/nri3707

[100] Taleb, S., Tedgui, A. and Mallat, Z. (2015) IL-17 and Th17 Cells in Atherosclerosis: Subtle and Contextual Roles. Arteriosclerosis, Thrombosis, and Vascular Biology, 35, 258-264. https://doi.org/10.1161/ATVBAHA.114.303567

[101] McInnes, I.B. and Schett, G. (2007) Cytokines in the Pathogenesis of Rheumatoid Arthritis. Nature Reviews Immunology, 7, 429-442. https://doi.org/10.1038/nri2094

[102] Armstrong, A.W., Harskamp, C.T., Ledo, L., et al. (2012) Coronary Artery Disease in Patients with Psoriasis Referred for Coronary Angiography. American Journal of Cardiology, 109, 976-980. https://doi.org/10.1016/j.amjcard.2011.11.025

[103] Armstrong, A.W., Harskamp, C.T. and Armstrong, E.J. (2013) Psoriasis and the Risk of Diabetes Mellitus: A Systematic Review and Meta-Analysis. JAMA Dermatology, 149, 84-91. https://doi.org/10.1001/2013.jamadermatol.406

[104] Armstrong, A.W., Harskamp, C.T. and Armstrong, E.J. (2013) Psoriasis and Metabolic Syndrome: A Systematic Review and Meta-Analysis of Observational Studies. Journal of the American Academy of Dermatology, 68, 654-662. https://doi.org/10.1016/j.jaad.2012.08.015

[105] Armstrong, A.W., Harskamp, C.T. and Armstrong, E.J. (2013) The Association between Psoriasis and Hypertension: A Systematic Review and Meta-Analysis of Observational Studies. Journal of Hypertension, 31, 433-443. https://doi.org/10.1097/HJH.0b013e32835bcce1

[106] Cosmi, L., Maggi, L., Santarlasci, V., Liotta, F. and Annunziato, F. (2014) T Helper Cells Plasticity in Inflammation. Cytometry Part $A, 85,36-42$.

https://doi.org/10.1002/cyto.a.22348

[107] Maradit-Kremers, H., Icen, M., Ernste, F.C., Dierkhising, R.A. and McEvoy, M.T. (2012) Disease Severity and Therapy as Predictors of Cardiovascular Risk in Psoriasis: A Population-Based Cohort Study. Journal of the European Academy of Dermatology and Venereology, 26, 336-343. https://doi.org/10.1111/j.1468-3083.2011.04071.x

[108] Langan, S.M., Seminara, N.M., Shin, D.B., et al. (2012) Prevalence of Metabolic Syndrome in Patients with Psoriasis: A Population-Based Study in the United Kingdom. Journal of Investigative Dermatology, 132, 556-562. https://doi.org/10.1038/jid.2011.365

[109] Naik, H.B., Natarajan, B., Stansky, E., et al. (2015) Severity of Psoriasis Associates with Aortic Vascular Inflammation Detected by FDG PET/CT and Neutrophil Activation in a Prospective Observational Study. Arteriosclerosis, Thrombosis, and Vascular Biology, 35, 2667-2676. https://doi.org/10.1161/ATVBAHA.115.306460

[110] Ahlehoff, O., Gislason, G.H., Lindhardsen, J., et al. (2011) Psoriasis Carries an Increased Risk of Venous Thromboembolism: A Danish Nationwide Cohort Study. PLOS ONE, 6, e18125. https://doi.org/10.1371/journal.pone.0018125

[111] Golden, J.B., McCormick, T.S. and Ward, N.L. (2013) IL-17 in Psoriasis: Implica- 
tions for Therapy and Cardiovascular Co-Morbidities. Cytokine, 62, 195-201. https://doi.org/10.1016/j.cyto.2013.03.013

[112] Speah, F. (2008) Inflammation in Atherosclerosis and Psoriasis: Common Pathogenic Mechanisms and the Potential for an Integrated Treatment Approach. British Journal of Dermatology, 159, 10-17. https://doi.org/10.1111/j.1365-2133.2008.08780.x

[113] Armstrong, A.W., Voyles, S.V., Armstrong, E.J., et al. (2011) A Tale of Two Plaques: Convergent Mechanisms of T-Cell-Mediated Inflammation in Psoriasis and Atherosclerosis. Experimental Dermatology, 20, 544-549. https://doi.org/10.1111/j.1600-0625.2011.01308.x

[114] Schüler, S., Brand, A., Klebow, S., Johannes, Wild, J., ProtásioVeras, F., Ullmann, E. Roohani, S., Kolbinger, F., Kossmann, S., Wohn, C., Daiber, A., Münzel, T., Wenzel, P., Waisman, A., Clausen, B.E. and Karbach, S. (2018) Antagonization of IL-17A Attenuates Skin Inflammation and Vascular Dysfunction in Mouse Models of Psoriasis. Journal of Investigative Dermatology, 139, 638-647.

[115] Wohn, C., Brand, A., Van Ettinger, K., Brouwers-Haspels, I., Waisman, A., Laman, J.D., et al. (2016) Gradual Development of Psoriatic Skin Lesions by Constitutive Low-Level Expression of IL-17A. Cellular Immunology, 308, 57-65.

https://doi.org/10.1016/j.cellimm.2015.11.006

[116] Madhur, M.S., Lob, H.E., McCann, L.A., Iwakura, Y., Blinder, Y., Guzik, T.J., et al. (2010) Interleukin 17 Promotes Angiotensin II-Induced Hypertension and Vascular Dysfunction. Hypertension, 55, 500-507. https://doi.org/10.1161/HYPERTENSIONAHA.109.145094

[117] Saleh, M.A., Norlander, A.E. and Madhur, M.S. (2016) Inhibition of Interleukin 17-A but Not Interleukin-17F Signaling Lowers Blood Pressure and Reduces End-Organ Inflammation in Angiotensin II-Induced Hypertension. JACC: Basic to Translational Science, 1, 606-616. https://doi.org/10.1016/j.jacbts.2016.07.009

[118] Huang, L.H., et al. (2018) Interleukin-17 Drives Interstitial Entrapment of Tissue Lipoproteins in Experimental Psoriasis. Cell Metabolism, 29, 475-487.

[119] Zhang, S., Yuan, J., Yu, M., Fan, H., Guo, Z.Q., Yang, R., Guo, H.P., Liao, Y.H. and Wang, M. (2012) IL-17A Facilitates Platelet Function through the ERK2 Signaling Pathway in Patients with Acute Coronary Syndrome. PLoS ONE, 7, e40641. https://doi.org/10.1371/journal.pone.0040641

[120] Hashmi, S. and Zeng, Q.T. (2006) Role of Interleukin-17 and Interleukin-17-Induced Cytokines Interleukin-6 and Interleukin-8 in Unstable Coronary Artery Disease. Coronary Artery Disease, 17, 699-706. https://doi.org/10.1097/01.mca.0000236288.94553.b4

[121] Jafarzadeh, A., Esmaeeli-Nadimi, A., Noughts, H., Nematoid, M. and Rezayati, M.T. (2009) Serum Levels of Interleukin (IL)-13, IL-17 and IL-18 in Patients with Ischemic Heart Disease. Anadolu Kardiyoloji Dergisi, 9, 75-83.

[122] Kalinina, N., Agrotis, A., Antropova, Y., DiVitto, G., Kanellakis, P., Kostolias, G., Ilyinskaya, O., Tararak, E. and Bobik, A. (2004) Increased Expression of the DNA-Binding Cytokine HMGB1 in Human Atherosclerotic Lesions: Role of Activated Macrophages and Cytokines. Arteriosclerosis, Thrombosis, and Vascular Biology, 24, 2320-2325. https://doi.org/10.1161/01.ATV.0000145573.36113.8a

[123] De Boer, O.J., Li, X., Teeling, P., Mackaay, C., Ploegmakers, H.J., Van Der Loos, C.M., Daemen, M.J., De Winter, R.J. and Van Der Wal, A.C. (2013) Neutrophils, Neutrophil Extracellular Traps and Interleukin-17 Associate with the Organisation of Thrombi in Acute Myocardial Infarction. Thrombosis and Haemostasis, 109, 
290-297.

https://doi.org/10.1160/TH12-06-0425

[124] Elnabawi, Y.A., Dey, A.K., Goyal, A. and Groenendyk, J.W., et al. (2019) Coronary Artery Plaque Characteristics and Treatment with Biologic Therapy in Severe Psoriasis: Results from a Prospective Observational Study. Cardiovascular Research, 115, 721-728.

[125] Zhang, L., Zhang, J., Su, S. and Luo, S. (2019) Changes in Interleukin-27 Levels in Patients with Acute Coronary Syndrome and Their Clinical Significance. PeerJ, 7, e5652. https://doi.org/10.7717/peerj.5652

[126] Rominger, A., Saam, T., Wolpers, S., Cyran, C.C., Schmidt, M., Foerster, S., Nikolaou, K., Reiser, M.F., Bartenstein, P. and Hacker, M. (2009) ${ }^{18}$ F-FDG PET/CT Identifies Patients at Risk for Future Vascular Events in an Otherwise Asymptomatic Cohort with Neoplastic Disease. Journal of Nuclear Medicine, 50, 1611-1620. https://doi.org/10.2967/jnumed.109.065151

[127] Mehta, N.N., Yu, Y., Saboury, B., Foroughi, N., Krishnamoorthy, P., Raper, A., Baer, A., Antigua, J., Van Voorhees, A.S., Torigian, D.A., et al. (2011) Systemic and Vascular Inflammation in Patients with Moderate to Severe Psoriasis as Measured by [18F]-Fluorodeoxyglucose Positron Emission Tomography-Computed Tomography (FDG-PET/CT): A Pilot Study. Archives of Dermatology, 147, 1031-1039. https://doi.org/10.1001/archdermatol.2011.119

[128] Voros, S., Rinehart, S., Qian, Z., Joshi, P., Vazquez, G., Fischer, C., Belur, P., Hulten, E.; Villines, T.C. (2011) Coronary Atherosclerosis Imaging by Coronary CT Angiography: Current Status, Correlation with Intravascular Interrogation and $\mathrm{Me}-$ ta-Analysis. JACC: Cardiovascular Imaging, 4, 537-548. https://doi.org/10.1016/j.jcmg.2011.03.006

[129] Ludwig, R.J., Herzog, C., Rostock, A., Ochsendorf, F.R., Zollner, T.M., Thaci, D., Kaufmann, R., Vogl, T.J. and Boehncke, WH. (2007) Psoriasis: A Possible Risk Factor for Development of Coronary Artery Calcification. British Journal of Dermatology, 156, 271-276. https://doi.org/10.1111/j.1365-2133.2006.07562.x

[130] Yiu, K.H., Yeung, C.K., Zhao, C.T., Chan, J.C., Siu, C.W., Tam, S., Wong, C.S., Yan, G.H., Yue,W.S., Khong, P.L., et al. (2013) Prevalence and Extent of Subclinical Atherosclerosis in Patients with Psoriasis. Journal of Internal Medicine, 273, 273-282. https://doi.org/10.1111/joim.12002

[131] Torres, T., Bettencourt, N., Mendonça, D., Vasconcelos, C., Gama, V., Silva, B.M. and Selores, M. (2015) Epicardial Adipose Tissue and Coronary Artery Calcification in Psoriasis Patients. Journal of the European Academy of Dermatology and Venereology, 29, 270-277. https://doi.org/10.1111/jdv.12516

[132] Honma, M., Shibuya, T., Iwasaki, T., Iinuma, S., Takahashi, N., Kishibe, M., Minami-Hori, M. and Ishida-Yamamoto, A. ((2017) Prevalence of Coronary Artery Calcification in Japanese Patients with Psoriasis: A Close Correlation with Bilateral Diagonal Earlobe Creases. The Journal of Dermatology, 44, 1122-1128. https://doi.org/10.1111/1346-8138.13895

[133] Balci, A., Celik, M., Balci, D.D., Karazincir, S., Yonden, Z., Korkmaz, I., Celik, E. and Egilmez, E. (2014) Patients with Psoriasis Have an Increased Amount of Epicardial Fat Tissue. Clinical and Experimental Dermatology, 39, 123-128. https://doi.org/10.1111/ced.12216

[134] Turner, J.E., Paust, H.J., Steinmetz, O.M. and Panzer, U. (2010) The Th17 Immune Response in Renal Inflammation. Kidney International, 77, 1070-1075. https://doi.org/10.1038/ki.2010.102 
[135] Hammerich, L., Heymann, F. and Tacke, F. (2011) Role of IL-17 and Th17 Cells in Liver Diseases. Clinical and Developmental Immunology, 2011, Article ID: 345803.

[136] Zhang, S., Huang, D., Weng, J., Huang, Y., Liu, S., Zhang, Q., et al. (2016) Neutralization of Interleukin-17 Attenuates Cholestatic Liver Fibrosis in Mice. Scandinavian Journal of Immunology, 83, 102. https://doi.org/10.1111/sji.12395

[137] Wang, Z., Shi, W., Liang, X., Wang, W. and Liang, J. (2016) Association of Interleukin 17/Angiotensin II with refractory Hypertension Risk in Hemodialysis Patients. African Health Sciences, 16, 766-771.

[138] McMaster, W.G., Kirabo, A., Madhur, M.S. and Harrison, D.G. (2015) Inflammation, Immunity, and Hypertensive End-Organ Damage. Circulation Research, 116, 1022. https://doi.org/10.1161/CIRCRESAHA.116.303697

[139] Elain, G., Jeanneau, K., Rutkowska, A., Mir, A.K. and Dev, K.K. (2014) The Selective Anti-IL17A Monoclonal Antibody Secukinumab (AIN457) Attenuates IL17A-Induced Levels of IL6 in Human Astrocytes. Glia, 62, 725-735. https://doi.org/10.1002/glia.22637

[140] https://acrabstracts.org/abstract/bms-986195-is-a-highly-selective-and-rapidly-actin g-covalent-inhibitor-of-brutons-tyrosine-kinase-with-robust-efficacy-at-low-dosesin-preclinical-models-of-ra-and-lupus-nephritis/

[141] https://www.globalbankingandfinance.com/can-fite-biopharma-ceo-letter-to-share holders/

[142] https://www.affibody.se/affibody-announces-initial-results-from-a-phase-i-study-of -aby-035/

[143] Huh, J.R. and Littman, D.R. (2012). Small Molecule Inhibitors of ROR yt: Targeting Th17 Cells and Other Applications. European Journal of Immunology, 42, 2232-2237. https://doi.org/10.1002/eji.201242740

[144] https://nuevolution.com/wp-content/uploads/2019/03/2-Page-Flyer-Nuevolution_F ebruary_2019.pdf

[145] Von Stebut, E., et al. (2019) Impact of Secukinumab on Endothelial Dysfunction and Cardiovascular Disease Parameters in Psoriasis Patients over 52 weeks. Journal of Investigative Dermatology, in press.

[146] ClinicalTrials.gov. Study to Explore the Effect of Secukinumab, Compared to Placebo, on Fat Tissue and Skin in Plaque Psoriasis Patients (ObePso-S). https://clinicaltrials.gov/ct2/show/NCT03055494

[147] https://www.corrona.org/ 